NBER WORKING PAPER SERIES

\title{
IMMIGRANT LABOR AND THE INSTITUTIONALIZATION \\ OF THE U.S.-BORN ELDERLY
}

\author{
Kristin F. Butcher \\ Kelsey Moran \\ Tara Watson \\ Working Paper 29520 \\ http://www.nber.org/papers/w29520 \\ NATIONAL BUREAU OF ECONOMIC RESEARCH \\ 1050 Massachusetts Avenue \\ Cambridge, MA 02138 \\ November 2021
}

We thank the National Institute on Aging at the NIH (1R03AG051861-01) and the Peterson Foundation's Project 2050 for financial support for this project. We thank Marissa Caldwell and Seha Karabacak for excellent research assistance and David Jaeger for providing country of origin definitions. We appreciate helpful feedback from participants at the Brookings Institution, the Essen Health Conference, Society of Labor Economists annual meetings, the Population Association of America Conference, the "All New Zealand" Economics seminar, and the Western Economic Association Conference. This material is based upon work supported by the National Science Foundation Graduate Research Fellowship Program under Grant No. 1122374. Any opinions, findings, and conclusions or recommendations expressed in this material are those of the author(s) and do not necessarily reflect the views of the National Science Foundation, the National Institutes of Health, the Peterson Foundation, or the National Bureau of Economic Research.

At least one co-author has disclosed additional relationships of potential relevance for this research. Further information is available online at http://www.nber.org/papers/w29520.ack

NBER working papers are circulated for discussion and comment purposes. They have not been peer-reviewed or been subject to the review by the NBER Board of Directors that accompanies official NBER publications.

(C) 2021 by Kristin F. Butcher, Kelsey Moran, and Tara Watson. All rights reserved. Short sections of text, not to exceed two paragraphs, may be quoted without explicit permission provided that full credit, including (C) notice, is given to the source. 
Immigrant Labor and the Institutionalization of the U.S.-born Elderly

Kristin F. Butcher, Kelsey Moran, and Tara Watson

NBER Working Paper No. 29520

November 2021

JEL No. I11,J14,J15,J61

\section{ABSTRACT}

The U.S. population is aging. We examine whether immigration causally affects the likelihood that the U.S.-born elderly live in institutional settings. Using a shift-share instrument to identify exogenous variation in immigration, we find that a 10 percentage point increase in the lesseducated foreign-born labor force share in a local area reduces institutionalization among the elderly by 1.5 and 3.8 percentage points for those aged 65+ and 80+, a 26-29 percent effect relative to the mean. The estimates imply that a typical U.S-born individual over age 65 in the year 2000 was 0.5 percentage points (10 percent) less likely to be living in an institution than would have been the case if immigration had remained at 1980 levels. We show that immigration affects the availability and cost of home services, including those provided by home health aides, gardeners and housekeepers, and other less-educated workers, reducing the cost of aging in the community.

Kristin F. Butcher

Department of Economics

Wellesley College

106 Central Street

Wellesley, MA 02481

and The Brookings Institution

and NBER

kbutcher@wellesley.edu

Kelsey Moran

Department of Economics

Massachusetts Institute of Technology

77 Massachusetts Avenue

Bldg E52-300

Cambridge, MA 02139

kmoran@mit.edu
Tara Watson

Department of Economics

Williams College

24 Hopkins Hall Drive

Williamstown, MA 01267

and NBER

tara.watson@williams.edu 


\section{Introduction}

The U.S. population is aging, with the population age 85 and older projected to grow from 2 percent today to 4 percent by the year 2040 (U.S. Census). This aging carries substantial costs, as 8 percent of total U.S. healthcare spending-or $\$ 286.2$ billion-was spent on nursing facilities and home health care in 2019 (CMS 2020). The vast majority of the elderly report that they would prefer to age in place (live in their homes) rather than live in an institution (Binette \& Vasold, 2018). Yet, more than 45 percent of those age 80 report some form of difficulty with cognition, mobility, sight, hearing, or self-care. ${ }^{1}$ Of those aged 65 and older with disabilities who remain in their communities, over 35 percent hire formal home care (Van Houtven et al. 2020). Currently, immigrants play a disproportionate role in caregiving and household services, particularly in roles that may be crucial complements to aging in place. This study examines whether immigration causally impacts the likelihood that the U.S.-born elderly age in place rather than live in an institutional setting.

The production of care for the elderly relies on a mix of less-educated labor, more-educated labor, and capital. Institutions serve as a way to share the fixed costs of capital, and the care that takes place in institutions tends to be more capital-intensive than home-based care. A robust supply of less-educated workers may lead to a different equilibrium in the production of caregiving services - one that is less capital intensive and more likely to be based in a home setting.

Earlier work suggests that immigrant labor supply affects household decisions in other contexts. For example, Cortes and Tessada (2011) find that an increase in immigration increases high-wage women's labor supply, presumably by allowing for the substitution of less-educated immigrant labor in home production. This study examines whether there is a similar link between immigrant labor and the production of elder care, which in turn is linked to the decision of the elderly to live outside of institutionalized settings.

\footnotetext{
${ }^{1}$ Authors' calculation using the 2017 American Community Survey. See Figure 1 for more information.
} 
We analyze whether U.S.-born elderly living in areas with more less-educated immigrant labor make different decisions about institutionalization. To address the potential endogeneity of the location choices of immigrants, we follow Bartel (1989), Altonji and Card (1991), and many others and use a shift-share instrument based on historical migration patterns. The instrument is the predicted share of the working-age population that is less-educated foreign-born; this prediction is based on 1970 immigrant residential patterns across U.S. commuting zones (CZs) interacted with subsequent changes in the national population of less-educated immigrants by country-oforigin. The first stage shows that the instrument indeed predicts the actual share of a CZ's labor force that is a less-educated and foreign-born. Notably, the shift-share instrument is less predictive in more recent years, so we focus our analysis on the 1980-2000 period. Recent work (Jaeger et al., 2018) highlights challenges of such shift-share instruments, and we discuss these below.

Using the shift-share instrument to predict immigrant labor supply in a CZ, we show there is a negative and statistically significant relationship between the less-educated foreign-born labor force share and institutionalization of the U.S.-born elderly. Our preferred specification suggests that a 10 percentage point increase in the less-educated labor force share is associated with a 1.5 percentage point reduced probability of living in an institution for those ages 65 and up, on a base of 5.2 percent, and a 3.8 percentage point lower probability for those ages 80 and up, on a base of 14.8. These effects represent 26-29 percent reductions relative to the mean. These results are robust to controlling for proxies for cohort health status.

To address the issue of selective migration of the elderly, we construct a secondary instrument based on birth state rather than current residence, using historical migration patterns of U.S. natives within the United States. The results using this alternative instrument are significantly negative and of comparable or larger magnitude, suggesting that selective migration of healthier elderly individuals to places with more immigrants is unlikely to be driving the main results. 
We focus on one possible mechanism for the finding: the labor market for caregiving and household services. We show that CZs with high predicted levels of immigration have lower wages among the less-educated workforce and increased employment of health and nursing aides. We see similar impacts for other less-educated occupations that may support home-based care, such as housekeepers and gardeners. By contrast, wages for more highly trained labor, such as registered nurses (RNs), increase and the quantity of hours worked falls.

In sum, our results suggest that the production of care for the elderly is indeed affected by immigration. U.S.-born elderly are less likely to live in institutions if they are in areas with more less-educated foreign-born labor. A likely mechanism for this finding is the reduced cost of inputs to aging in the community such as caregiving and household services.

The remainder of the paper is organized as follows. Section II presents background on the issue of immigration and the production of elder care. Section III discusses the data and methodology. Section IV presents the results. Section V examines potential mechanisms. Section VI concludes.

\section{Background}

\section{A. The Aging of the Population and Age-Related Morbidity}

It is well-known that the population of elderly is growing in the U.S. The number of 85-plus-yearolds will more than double to 14 million by the year 2040, as will the ratio of 85-plus individuals to 18-to-64 individuals (U.S. Census Bureau 2017). This coming demographic change will have wide-ranging economic impacts, including increased demand for caregiving services for the elderly. Figure 1 shows that, by the age of 65, 22 percent of individuals in the 2017 American Community Survey (ACS) report experiencing difficulty with independent living or self-care; this share increases to 59 percent by age 85 . Similarly, using data from the 2002 and 2004 Health and 
Retirement Study (HRS), ${ }^{2}$ Appendix Figure 1 shows that the fractions of non-institutionalized individuals who report having difficulty with activities of daily living (ADLs) or instrumental activities of daily living (IADLS) increase sharply with age, where ADLs are defined as basic selfcare tasks - such as bathing or eating - and IADLs are defined as everyday tasks to take care of oneself and one's home that require more complex planning and thinking-such as shopping for groceries or managing money. ${ }^{3}$ About half of individuals reporting difficulties with ADLs or IADLs receive help from others, a share that also increases with age. In addition, Panel C of Appendix Figure 1 shows that individuals become increasingly likely to outsource home and garden care as they age. Clearly, as a higher share of people reach their 80 s and beyond, the need for eldercare is expected to rise.

\section{<PLACE FIGURE 1 HERE $>$}

\section{B. The Production of Elder Care}

The production of elder care requires a combination of highly-educated labor, less-educated labor, and capital. These factors of production may be combined in different ways to produce a given amount and quality of care-giving. Consider two types of production technologies: private homes versus institutionalized care. The former will be relatively less capital intensive and require more labor, particularly less-educated labor, as the elderly may need assistance with shopping, cleaning, yardwork, and home maintenance that goes along with maintaining an private home. Alternatively, the elderly may be densely housed in a capital-intensive institutional environment. A denser living environment means that one caregiver can provide services to a larger number of people-potentially using specialized equipment-and the institutional production of care-giving will tend to be more capital-intensive.

\footnotetext{
2 Since our main analyses use Census data from 1980 to 2000, we use the 2002 and 2004 HRS for these descriptive statistics. We combine the two survey years for more precision at each age.

${ }^{3}$ We classify an individual in the HRS as having a difficulty with ADLs if they report having any difficulties with dressing, walking, bathing, eating, getting in or out of bed, or using the toilet. We classify an individual as having a difficulty with IADLs if they report having any difficulties with either preparing a hot meal, shopping for groceries, making phone calls, taking medications, or managing money.
} 
The choice of production technology will depend on many things, including the health of the elderly individual. If one needs frequent access to skilled medical care and medical equipment or technology with high fixed costs, the institutional setting is likely the most cost-effective option. On the margin, however, the decision about the production of care may depend on the availability of less-educated labor in the local area. Consider, for instance, an 80-year-old living in a private home who is now experiencing mobility challenges. If it is relatively easy and affordable to hire someone to do some shopping and housework and to help with personal care, she is more likely to continue living in the community. Similarly, an adult daughter who can outsource housework or child care might be in a better position to provide support to her elderly mother. ${ }^{4}$ By increasing the supply of less-educated labor in the local labor market, immigration may have an effect on the choice of production technologies for elder care. Relatedly, immigration may improve the quality of these support services; Cortes and Pan (2015) show that nurses from the Philippines are positively selected and of high skill relative to U.S.-born nurses, for example.

Previous research has found in other contexts that the type of labor available in the local labor market affects the choice of production technology. Lewis (2011) demonstrates that when there is more low-skilled labor available in the local labor market due to immigration, the choice of production technologies shifts toward less-educated labor, and Clemens, Lewis, and Postel (2018) find evidence that restricting immigrant labor supply affects agricultural technology

\footnotetext{
${ }^{4}$ Elder care given by family members may be combined with both formal and informal in-home care. For example, using Austrian administrative data, Frimmel et al. (2020) find that an abrupt health shock (stroke or heart attack) of a parent reduces adult children's labor supply, particularly that of daughters. Their work also gives insight into the role of immigration in mediating this relationship: during the period of study, the Austrian government exempted migrant care workers from migration restrictions for citizens of Central and Eastern EU member countries, resulting in a large increase in the supply of formal care provided by migrant workers. The effect of a parental health shock on children's labor supply is smaller after this reform, suggesting that the labor of migrant care workers allows adult children to supply more labor to the market. Van Houtven et al. (2020) discuss the ways in which purchased care might combine with informal care provided by family and friends: the elderly report strongly preferring to remain outside an institutional setting, but they also report that they would prefer formal home care over informal home care if they need care in the future. And formal and informal care may be complements in some contexts. As Van Houtven et al. (2020) state, "formal home care may allow informal caregivers to focus on different tasks that need attention as the care recipients' needs change."
} 
adoption. Cortes and Tessada (2011) show that when the local labor market has more immigrants, high-skilled women supply more labor because they are able to substitute immigrant labor for their own in household production. ${ }^{5}$ Relatedly, Cortes (2008) finds that increases in immigration result in lower costs of immigrant-intensive household services, such as housekeeping and gardening. ${ }^{6}$ Here, we examine whether the choice of production of eldercare at home versus in an institution is affected by the composition of the local labor market.

In addition to potentially influencing the choice of home versus institutional care, production of care within institutions may also be affected by labor supply. Miller et al. (2009) find that mortality of the elderly in nursing homes is elevated in tight labor markets, presumably because the quality of care in institutions caring for the elderly declines as it is more difficult to staff these jobs when unemployment is low. Immigration, on the other hand, may increase the labor available to staff nursing homes. Furtado and Ortega (2020) find that increases in immigration are associated with fewer falls among the elderly in institutions, particularly in competitive markets. Using a similar methodology, ${ }^{7}$ Grabowski, Gruber, and McGarry (2020) find that immigration increases nursing home staffing and quality.

Immigration, then, may affect both in-home care options and institutional care for the elderly. In-home care likely offers more flexible support: it can be provided by family members or by someone who is paid, and the intensity of care can vary with need (Mommaerts, 2018). As Mommaerts (2018) notes, "[n]ursing homes, on the other hand, offer a package of services that may be excessive for many individuals, yet suitable (or even necessary) for those who require more intensive care."

\footnotetext{
${ }^{5}$ Similarly, East and Velasquez (2018) find that increased federal deportation of undocumented immigrants through the Secure Communities program reduced the labor supply of high-skilled women, particularly for mothers with young children, due to the increased cost of childcare and household services.

${ }^{6}$ Appendix Table 1 uses the HRS to describe who the helpers are for the over 55 population. For those who receive help with ADLs and IADLs, spouses are the most likely to give it. However, receiving help from daughters and "other" (non-relatives) is also very common.

${ }^{7}$ Grabowski et al. (2020) amend the shift-share instrument strategy by weighting national immigrant flows by the ethnic groups' likelihood of working in nursing homes.
} 
Immigrant labor might have a disproportionate effect on the choice of production technologies for elder care. As we have shown in earlier work (Butcher \& Watson, 2019), the foreign-born comprise a disproportionate share of occupations that the elderly may rely on to age in place. Appendix Figure 2 illustrates the immigrant labor share in key occupations for 1980, 2000, and 2017. Immigrants are more likely than the general population to work as health and nursing aides and housekeepers and gardeners, and the share of these occupations that are foreign-born has been increasing over time.

This study assesses the net impact of immigration on the probability of living in an institution. While immigration might affect the quality and cost of eldercare in both the institutional and inhome setting, there are reasons to believe the rate of institutionalization will be affected. First, it is likely that, relative to nursing home expenses, the cost of in-home care is particularly sensitive to immigration because the provision of this care is more labor-intensive. Second, one of the barriers to aging in the community may be the search costs of finding someone to provide this type of help; if there are more immigrants in the local area, it may be much easier to arrange the services needed. ${ }^{8}$ Finally, if immigrants are undocumented, it is likely that their presence in the local labor market has a larger effect on supply of labor to home production than to formal institutional care.

It is ultimately an empirical question whether institutionalization of the elderly is affected by immigration. Considering that about eighty percent of those aged 50 and up say that they would prefer to age in place rather than live in a nursing home (Binette \& Vasold, 2018), ${ }^{9}$ it is of primary importance to understand whether immigration-driven local labor supply affects elderly institutionalization decisions.

\section{Data and Methods}

\footnotetext{
${ }^{8}$ Note that some of the services needed may be alterations to a home-for example, to install handrails, ramps, and other safety equipment-and immigrants are also very likely to work in construction. Eriksen et al. (2015) find evidence that home safety/accessibility features reduce falls and may reduce the likelihood of a nursing home stay. ${ }^{9}$ Work by Engelhardt et al. (2005) also finds that the elderly report a preference for independent living and thatconsistent with that reported preference-higher incomes are associated with higher rates of living independently.
} 
We use the Integrated Public Use Microdata Surveys (IPUMS) to obtain individual-level survey data from decennial U.S. Censuses and the American Community Surveys (ACS) (Ruggles et al., 2019). The primary sample is U.S.-born individuals ages 65 and up in the Census public use samples for 1980, 1990, and 2000. We also use 1970 Census to identify historical immigration and internal migration patterns which serve as the basis for our instruments, and we use more recent ACS data from 2010 and 2017 to examine the validity of the shift-share instrument in a more recent period. The primary sample is U.S.-born individuals ages 65 and up. Selected summary statistics for the sample are presented in Table 1, with additional details in Appendix Table 2.

<PLACE TABLE 1 HERE $>$

Institutionalization among U.S.-born elderly is the key outcome of interest. Our primary analyses use decennial U.S. Censuses, which do not allow us to identify the type of institution in which an individual resides. In other words, prisons, nursing homes, and other types of institutions are indistinguishable. Though roughly 85 percent of institutionalized men under age 40 are in a correctional institution, the institutionalized elderly are typically in an institution associated with elder care (see Butcher and Piehl 1998 for a discussion), and institutionalized status serves as a reasonable proxy for caregiving arrangements of the elderly.

Figure 2, based on decennial U.S. Censuses and American Community Surveys, shows the fraction institutionalized by age for selected years. Consistent with the patterns of self-reported disability by age shown in Figure 1, institutionalization rates increase rapidly after age 75 . One can also see that there is a secular reduction in institutionalization rates of the elderly at any given age over time. The institutionalization rate of 85-year-olds in 2017 is about the same as that of 75-yearolds in 1990, for example. Compositionally, this move away from institutionalization appears to be due to both lower rates of disability for the elderly at each age and a reduction in institutionalization rates among those with reported difficulties. 
We assess whether the share of the working age population that is less educated and foreignborn affects the living arrangements of the elderly in a local area. We use commuting zones (CZs) as the unit of geography because CZs cover the United States and closely map to a local labor market. Following Autor and Dorn (2013) and Autor, Dorn and Hanson (2019), we map the geographic information available in the public-use Census and ACS onto CZs and adjust the weights to reflect the allocation of individuals across CZs. ${ }^{10}$

We are interested in the following relationship:

$$
\text { inst }_{i z t}=\beta \text { ShareLEImm } z t+X_{i z t} \alpha+\gamma_{z}+\lambda_{t}+\mu_{i z t}
$$

where inst $_{i z t}$ is a binary variable representing whether an individual $i$ in commuting zone $z$ at time $t$ lives in an institution. The variable Share LE $/ \mathrm{mm}_{z t}$ refers to the fraction of the working-age (ages 16-64) population in commuting zone $z$ at time $t$ that is less-educated (defined as completing less than one year of college) and foreign-born. A vector of individual-level controls $X_{i z t}$ includes birth state*race/ethnicity fixed effects, year*age*race/ethnicity fixed effects, gender*marital status fixed effects, and education in four categories (high school graduate, some college, college

\footnotetext{
${ }^{10} \mathrm{CZs}$ are defined as collections of U.S. counties that have strong commuting ties to each other and weak ties to other areas (Tolbert \& Sizer 1996, Autor \& Dorn 2013). CZs thus differentiate local labor markets under the assumption that employers and workers in a local market should be located within commutable distances. To map the available information in the U.S. Census Public Use Files to CZs, we follow the methodology established in Autor and Dorn (2013). We utilize their crosswalk files, which include a probabilistic matching of sub-state geographic units (e.g., county group, PUMA) in the Census data to CZs. We then replace every individual microdata observation with 722 observations that are identical to the initial observation with the exception that the person weight is adjusted from the initial Census person weight to that initial weight multiplied by the fraction of that observation's sub-state geographic unit that maps to the given CZ. Many of these fractions are zero, and those observations are discarded. This procedure thus creates some duplicate observations for people living in sub-state geographic units that span multiple CZs. We use the revised weight in all of our analyses in order to not overweight these individuals. In practice, many sub-state geographic units match fully into a single CZ. For example, of the 2071 PUMAs in the 2000 Census, only 19\% overlap with several CZs. All tables report both the number of unique observations in the data as well as the number of observations (including duplicates) from the CZ mapping procedure.
} 
graduate and up, with less than high school graduate omitted). We control for commuting zone fixed effects $\gamma_{z}$ to account for time-invariant factors that could affect the level of institutionalization in a local area. We also control for year fixed effects $\lambda_{t}$ to account for national trends in institutionalization rates. The key coefficient of interest $\beta$ is therefore identified based on differentially changing shares of less-educated immigrants across commuting zones over time.

As has been widely recognized in the literature, immigrants tend to locate in areas with favorable economic conditions. Economic conditions could also affect the choice of production technology for elderly caregiving, thus generating a bias in the estimation of equation (1) examining the impact of immigration on living arrangements. We address this bias by using a commonly used shift-share instrumental variables strategy to predict ShareLElmm ${ }_{z t}{ }^{11}$ The shift-share instrumental variables approach exploits the fact that immigrants are likely to move to places where their co-nationals have settled in the past. Thus, variation in the size of immigrant inflows across different commuting zones is partially determined by historical settlement patterns, along with global factors affecting national immigrant inflows to the United States from different nations over time. For example, an influx of immigrants from Cuba to the United States would be likely to particularly affect Miami, whereas an influx of immigrants from China would have a larger effect on San Francisco.

To translate this idea into an instrument reflecting predicted less-educated immigrant share in commuting zone $z$ in year $t$, two components are required. The first component (the "base share") reflects the historical distribution of immigrants from country of origin group $j$ across CZs $z$ in the base year $1970 .{ }^{12}$ It is the ratio in 1970 of the foreign-born population from country group $j$ living in commuting zone $z$ to the total population from country group $j$ living in the United States. We rely on 39 country of origin groups suggested by Jaeger et al. (2019) to have adequate representation in the 1970 Census data. This base share component of the instrument is time-

\footnotetext{
${ }^{11}$ See Bartel (1989), Altonji and Card (1991), Lewis (2011), Cortes and Tessada (2011), and Furtado and Ortega (2020), to list but a few.

12 We follow Jaeger et al. (2018) in using 39 countries of origin and origin groups, in order to avoid having small, inconsistently defined country of origin groups over time. Jaeger et al. limits the analysis to separately identifying the country of origin groups with at least 5,000 observations in the 1990 census.
} 
invariant and is based on the full immigrant population regardless of age or education. It is reflected in equation 2 :

$$
\text { (2) } \text { BaseShare }_{j z 70}=\frac{\text { ImmPop }_{j z 70}}{\operatorname{ImmPop}_{j 70}}
$$

The base share is specific to country of origin group $j$. Figure 3 illustrates the base share for three different country of origin groups: Mexico (Panel A), China (Panel B), and Italy (Panel C). Some CZs, such as those containing Chicago and Los Angeles, were popular destinations for immigrants in 1970 and thus have large shares of the foreign-born from each country of origin. In other CZs, though, these shares vary widely by origin group. Immigrants from Mexico in 1970 were more likely to be living in CZs along the U.S.-Mexico border, while those from China were more likely to be living along the Northwest and Northeast coast, and those from Italy were more likely to be living in CZs in the Northeast.

\section{<PLACE FIGURE 3 HERE $>$}

The second component of the instrument (the "shift") takes account of the changing numbers of the less-educated working-age immigrant population from different countries that are living in the United States at a given point in time. For each country group $j$, the total U.S. population of less-educated (LE) working-age (WA) immigrants at time $t$ is reflected by LE Imm WAPop ${ }_{j t}$. These two components are then multiplied to create a predicted number of less-educated working-age immigrants from country $j$ in commuting zone $z$ at time $t$, as shown in equation (3):

$$
\text { (3) } \text { PredictedLEImmWAPop }_{j z t}=\text { BaseShare }_{j z 70} * L E I m m \text { WAPop } \text { Imt }_{j}
$$

The next step is to aggregate this predicted population across country of origin groups to generate a predicted less-educated working age foreign-born population in commuting zone $z$ at time $t$. This predicted number is then divided by the total working age population in commuting zone $z$ at time $t$ to produce a predicted share of the overall working age population in the CZ that is a less-educated immigrant: 
(4) PredictedShareLEImm It $_{z}=\frac{\sum_{j} \text { Predicted LE Imm WAPop }}{\text { WAPop }_{z t}}$

The predicted share less-educated immigrant shown in equation (4) serves as the excluded instrument in the first stage. The instrument varies by commuting zone $z$ and year $t$. Because we control for commuting zone fixed effects, variation in this instrument reflects percentage point changes in the predicted share of a CZ's working age population that is foreign-born and lesseducated over time. Figure 4 shows the percentage point change in the instrument between 1980 and 2000. Though the Northeast had high numbers of immigrants in 1970, the origin groups that arrived in subsequent decades are predicted to be largely concentrated in the Southwest and West. The largest increase in the predicted share occurs in a CZ in Texas, where the predicted share of the working age population that is less-educated and foreign-born increased from $45 \%$ in 1980 to $211 \%$ in 2000 (thus representing a predicted 166 percentage point increase).

\section{$<$ PLACE FIGURE 4 HERE $>$}

In the first stage, the shift-share instrument from equation (4) is used to predict the endogenous regressor (ShareLEImm $m_{z t}$, the observed share of the working age population that is less-educated and foreign-born in commuting zone $z$ in year $t$ ). The percentage point change in the endogenous regressor is shown in Figure 5. As expected, there are differences between the endogenous regressor (the observed less-educated foreign born share) and the instrument (the predicted share). The largest increase in the observed share is 20 percentage points-representing five different CZs whose actual share of the working age population that is less-educated and foreignborn increased from $2 \%$ in 1980 to $22 \%$ in 2000 . This is much smaller than the largest increase in the predicted share (166 percentage points, shown in Figure 4). In addition, Figure 5 shows the emergence of some new immigrant destinations different from those depicted in Figure 4. Immigration to these areas is not captured by variation in the instrument and therefore by design does not help identify estimated impacts of immigration on elderly institutionalization.

<PLACE FIGURE 5 HERE> 
Though the first stage could be run at the commuting zone-year level, we use individual-level data from our primary sample (U.S.-born individuals ages 65 and up) to align the first and second stages of the analysis. The weights therefore reflect the elderly population in each commuting zone, and standard errors are clustered at the commuting zone level to account for serial correlation. The first stage controls for the same individual-level controls described above, including birth state*race/ethnicity fixed effects, year*age*race/ethnicity fixed effects, and gender*marital status fixed effects.

Overall, this strategy exploits the tendency of immigrants to migrate to places in which there are already established immigrant communities from their home countries. The IV relevance requirement for this instrument is that 1970 immigrant migration patterns must be predictive of the migration patterns of less-educated working-age immigrants from the same country-of-origin in later years. We will show that this is indeed the case when we present first stage results in the next section.

The main identifying assumption for our analysis is the standard 2SLS exclusion restriction that, conditional on controls, our shift-share instrument is uncorrelated with factors other than immigration that could affect the living arrangements of the native-born elderly. Since the instrument is a function of national immigrant inflows and local historical immigrant shares, the following two assumptions must hold: first, any unobserved factors that determine the location of immigrants in different CZs across the U.S. in 1970 must not be correlated with changes in elderly institutionalization across different CZs during the later years in our sample; second, the total (national) number of less-educated immigrants in the U.S. in any given year must be exogenous to differential time varying shocks in individual U.S. CZs.

There are potential threats to the validity of this exclusion restriction. First, the U.S.-born elderly could migrate to take advantage of immigrant labor supply in a way that is correlated with unobservable health conditions, thereby creating a spurious relationship between immigration 
and caregiving arrangements. Below, we consider an alternative instrument which accounts for selective migration of the elderly. In addition, we control for a proxy for prior health status - the lagged institutionalization rate for the cohort in question.

A second threat to validity is pointed out by Jaeger et al. (2018). There is persistence in immigrant inflows such that shift-share immigration in recent decades within a CZ is serially correlated, thereby making it impossible to distinguish between short- and medium-run impacts of immigration. We confirm this finding in our context. Since it likely takes time for markets to evolve, and since institutional status is measured as a stock rather than a flow, we believe medium run effects are most relevant for our analysis. We return to this concern below.

Finally, we explore the labor market mechanism for the relationship observed in the instrumental variables analysis by running CZ-level instrumental variables analyses of labor market wages and employment by occupation. These analyses are of the form:

$$
\text { outcome }_{z t}=\beta \text { ShareLEImm } z t+\gamma_{z}+\lambda_{t}+\mu_{z t}
$$

where ShareLEImm $m_{z t}$ is instrumented using the shift-share instrument described above.

\section{Results}

\section{A. Ordinary Least Squares results}

We start by estimating equation (1) to understand the OLS relationship between the share of the working age population that is less-educated and foreign-born and institutionalization of those ages 65 and up, controlling for individual characteristics, CZ fixed effects, and year fixed effects. The results are shown in Panel A of Table 2. Because, as described below, the instrument does not function well in all time periods, our preferred specification limits the investigation to the 1980, 1990, and 2000 Censuses. Using this 1980-2000 sample in column (1), we see a negative 
and statistically significant OLS relationship: a 10 percentage point increase in immigrant share is associated with a 0.76 percentage point reduction in the probability of living in an institution, on a base of 5.2 percent. The OLS relationship is fairly similar when we omit 1990 and just look at the long difference 1980-2000 (see column (2) of Panel A).

\section{<PLACE TABLE 2 HERE >}

The negative association between immigration and institutionalization is still evident when incorporating 2010 and 2017 samples into the analysis. The coefficients in columns (3) and (4) are negative and statistically significant, though somewhat smaller in magnitude than those using the 1980-2000 sample. In columns (4) through (8), we examine the relationship on a decade-bydecade basis. Point estimates are consistently negative, but results are insignificant for the 20002010 period and the $2010-2017$ period.

Regardless of the time period, the OLS regressions are unlikely to recover the true causal impact of immigration on living arrangements of the elderly. We therefore turn to the two-stage least squares analysis.

\section{B. First-stage results}

As noted above, the left-hand-side variable in the first stage is the share of the working-age population in CZ $z$ in year $t$ that is less-educated and foreign-born. The right-hand-side includes the shift share instrument which predicts the share of the working-age population in $\mathrm{CZ} z$ in year $t$ that is less-educated and foreign-born as a function of 1970 immigrant settlement patterns interacted with national country-of-origin immigrant inflows.

Panel B of Table 2 presents the first stage results. The first column shows the preferred 19802000 sample and indicates that a 10 percentage point increase in the instrument (the predicted share of less-educated working age immigrants) is associated with approximately a 3.2 
percentage point higher share of less-educated immigrants in the working-age population. Results are similar when we omit 1990 and focus on the long difference between 1980 and 2000. We also show results incorporating 2010 and 2017 in columns (3) and (4); these coefficients are still positive but smaller in magnitude.

To test the strength of the instrument, we follow the recommendation of Andrews, Stock, and Sun (2019) and calculate the Kleibergen and Paap (2006) rk Wald F statistic and then compare it to the Stock and Yogo (2005) critical value of 23.1. ${ }^{13}$ These F-statistics are presented in Panel C of Table 2. We can reject weak instruments for columns (1), (2), and (3).

The decade-by-decade analysis in columns (4) through (8) of Panel B shows a less robust pattern and exhibits a wrong-signed relationship between 2000 and 2010. This negative coefficient suggests that, between 2000 and 2010, labor markets that would have been expected to receive more immigration based on historical patterns and national inflows actually experienced slower growth in immigrant shares. The pattern reverses to its typical positive association in the 20102017 period. Given this temporary break from precedent in the early 2000 s, we focus our analysis on the 1980-2000 period. For completeness, we also include appendix tables that include sample years 2010 and 2017, and they corroborate the findings from our preferred sample.

\section{Main results}

Panel C of Table 2 presents the two stage least squares (2SLS) analysis. The dependent variable is an indicator equal to one if the individual is living in an institution. As described above, the

\footnotetext{
${ }^{13}$ The empirical literature frequently reports the first stage F-statistic and compares its value to either the Staiger and Stock (1997) rule-of-thumb cutoff of 10 or to the number-of-instruments-specific critical values reported in Stock and Yogo (2005). However, this testing method for weak instruments is only valid when the data is independent and homoskedastic. Our main specification includes heteroskedastic and cluster-dependent error terms. We thus report the Kleibergen-Paap Wald statistic, which is robust to nonhomoskedasticity and also equivalent to the Montiel Olea and Pflueger (2013) efficient first-stage F-statistic in settings with a single endogenous regressor and a single instrument.
} 
right-hand-side variable is the share less-educated foreign-born among the working-age population in the $\mathrm{CZ}$; this is instrumented using the shift-share instrument.

The main result is shown in column (1) of Table 2, Panel C. Here we see that a 10 percentage point increase in the less-educated immigrant share in the working age population is associated with a 1.5 percentage point decline in the probability of an elderly person being institutionalized, on a base rate of 5.2 percent. Given the average increase of 3.3 percentage points in lesseducated immigrant share between 1980 and 2000, this implies that a typical U.S-born individual over age 65 in the year 2000 was 0.5 percentage points (10 percent) less likely to be living in an institution than would have been the case if immigration had remained at 1980 levels. The results suggest a comparable magnitude using the long difference 1980-2000 (column (2)) and a larger magnitude when incorporating 2010 and 2017 (column (3)), or the 1980-2017 long difference (column (4)).

Our preferred instrumental variable estimates are roughly double the size of the OLS estimates. Assuming the instrumental variable approach we are using is valid, this is consistent with the notion that immigrants are moving into commuting zones where unobserved factors are tending to increase (or, more accurately, slow the secular decline in) the institutionalization among the elderly. Alternatively, the variation exploited by our instruments (which depends on social network-based migration) may have a different local average treatment effect than the general treatment effect of less-skilled immigration.

In Table 3, we explore how the relationship between immigration and institutionalization varies across demographic subgroups. Panel A explores the 1980-2000 sample for U.S.-born individuals ages 65 and up. We see only modest differences by race/ethnicity, educational attainment, or gender of the older person, with most subgroups having a 2 to 4 percent reduction in institutionalization relative to the mean institutionalization rates for every percentage point increase in immigrant share. The one exception is the effects for the Hispanic ethnicity subsample which are imprecisely estimated due to small sample sizes. Panel B repeats the subsample 
analysis for age 80 and up. Results are larger in magnitude for the older group, but effect sizes still remain 2 to 4 percent of baseline institutionalization rates for most groups. Appendix Table 3 shows these results for the 1980-2017 sample and shows somewhat more variability across demographic groups, with most effect sizes in the 4 to 8 percent range.

\section{<PLACE TABLE 3 HERE $>$}

\section{Accounting for Selective Migration Among the Elderly}

A natural concern is that post-retirement migration decisions of the elderly may be endogenous to their health, and thus may have an effect on their institutionalization probabilities. ${ }^{14}$ If, for example, healthier individuals migrate to or are less likely to move away from areas with higher immigrant shares, a spurious negative relationship between immigration and institutionalization could be observed. This could occur even if immigrant location was randomly assigned if the elderly based their own migration decisions on the location of immigrants. The Census data does not measure self-reported health status or disability consistently over the 1980-2000 period, so it is difficult to examine endogenous migration directly.

We try two approaches to address the selective migration issue. First, we generate an alternative instrument which marries the traditional shift-share instrument for immigration with expected migration patterns based on state of birth. Specifically, we use 1970-1980 data to identify a timeinvariant probability, BaseEldShare ${ }_{b z 7080}$, that an individual age 65 and older born in state $b$ will reside in commuting zone $z$. For example, a person born in New York is more likely to retire in West Palm Beach than is a person born in Oregon, regardless of the immigrant inflows. We then multiply these probabilities by Predicted ShareLEImm St $_{\text {for }}$ an individual born in state $b$ observed in year $t$ and sum over all CZs:

\footnotetext{
${ }^{14}$ Although we are concerned about selective migration among the elderly, mobility is higher at younger ages. In results not shown, we use the combined 2013-2017 ACS to examine migration in the past year (the only measure available). For those age 65 and above, about 45 percent live outside their state of birth. However, among those who live outside their state of birth, only about 0.8 percent moved in the last year. Similarly, only about 1.4 percent of those age 65 and up report moving from another state (or from abroad) in the past year.
} 
(5) AltPredicted ShareLEImm It $_{b}=\left[\sum_{z}\left(\right.\right.$ BaseEldShare $_{b z 7080} *$ PredictedShareLEImm $\left.\left._{z t}\right)\right]$

AltPredicted ShareLEImm St $_{\text {in }}$ is alternative instrument that varies at the birth state-year level and does not depend on the current CZ or migration decisions of the focal individual. In this sense, it is a slightly more sophisticated version of an instrument using future predicted immigrant shares in an individual's state of birth. The alternative instrument, in principle, avoids the issue of endogenous migration of the elderly in response to immigrant location.

Results using the alternative instrument AltPredicted ShareLE Imm $_{b t}$ are shown in Table 4. Panel A shows the first stage, which represents a strong relationship between the predicted exposure to less educated immigrants based on birth state and the actual exposure. In Panel B of Table 4, results of the two-stage-least squares analysis are shown. Point estimates are highly significant and larger in magnitude than those using the standard instrument (see Panel C of Table 2). It is important to note that this instrument captures a different local average treatment effect than the primary instrument used above because "compliers" are those whose geographic location in old age is consistent with historical patterns. Overall, though, these results suggest that selective migration of the elderly is unlikely to be driving the main findings. Results are similar using the 1980-2017 sample, as shown in Appendix Table 4.

\section{<PLACE TABLE 4 HERE>}

A second approach to addressing selective migration is to control for prior health status. We do not have individual-level panel data, but we can construct synthetic cohorts on the basis of fiveyear birth year groupings to generate proxies for health status. ${ }^{15}$ Specifically, we consider the share of the cohort that lived in an institution in a prior time period as a measure of unobserved health. Cohorts are defined in one of two ways: based on current CZ residential location or based on state of birth.

\footnotetext{
${ }^{15}$ There is, unfortunately, inadequate data to use individual year of birth groupings to generate these proxies.
} 
For the current $\mathrm{CZ}$ of residence approach, we calculate the institutionalization rate for those in the same birth year group residing in the $\mathrm{CZ}$ ten years prior. For example, for a 72-year-old in the 1980 census, we calculate the fraction of the 1970 sample ages 60 to 64 in the same CZ that were residing in an institution. The historical CZ controls also help account for unobserved characteristics of or policies in the local area that may have affected institutionalization in a prior period. Due to the fact that CZ is unobservable prior to 1970, we cannot use proxies for cohort health status with more than a 10-year lag. As an alternative, we calculate the lagged institutionalization rate of those in the same birth state and birth year group, regardless of current residence. Here, we construct institutionalization rates for the birth state-birth year group cohort 10, 20, and 30 years prior.

Table 5 presents the results of the analysis controlling for these lagged cohort institutionalization rate health proxies. Column (1) repeats the baseline results from Table 2. In column (2), we find that the 10-year lagged CZ-based health proxy does strongly predict institutionalization rates. However, it has no substantive impact on the main coefficients of interest. The same is true using the 10-year lagged proxy based on birth state in column (3). As the lags get larger in columns (4) and (5), they are less predictive of current institutionalization status, but in no case do including these controls qualitatively change the main results. Columns (6) through (10) repeat this exercise for the age 80 and up subsample. We similarly see that controlling for lagged institutionalization does not substantively change the coefficient of interest. It therefore appears unlikely that our main findings are driven by selective migration of the elderly based on health status. The findings are corroborated using the 1980-2017 sample in Appendix Table 5.

\section{<PLACE TABLE 5 HERE>}

E. Responding to Jaeger et al. (2018) and Robustness 
Jaeger et al. (2018) raise concerns about the use of the standard immigration shift-share instrument. In the U.S. context, the instrument shows a high degree of persistence within local areas over time, thereby making it impossible to distinguish between the effect of immigration that occurred this year and the effect of immigration that occurred years or even decades previously. If immigration inflows years ago continue to have dynamic impacts, these will be conflated with the impacts of current inflows, generating biased estimates of the effect of immigration.

In the context of institutionalization, we argue that the medium run is the appropriate time frame to consider. We observe institutionalization as a stock variable at a point in time, which reflects a series of historical decisions. In addition, we expect it will take time for local labor markets and caregiving institutions to react to changes in the local labor market. Therefore, we think of the estimated effect as capturing both the lagged results of immigration in the past as well as current migration. Consistent with this view, estimating the model using a long difference 1980-2000 (i.e. excluding 1990) shows comparable results to the main finding, as discussed previously and reported in column (2) of Table 2.

To separate the medium- and short-run impacts of immigration, Jaeger et al. (2018) suggest instrumenting for both the current level of immigration and the lagged level, where a one-decade lag is deemed appropriate for picking up effects of cumulative migration to that point. The instruments are the standard shift-share instrument and its lag. We implement this procedure in Table 6. Column (1) repeats the baseline result without lags. Column (2) shows that we lack the power to separately identify the effect of current and lagged immigration, consistent with the key finding of Jaeger et al. (2018). Both the Kleibergen-Papp rk Wald F statistic and the Kleibergen-Paap rk Lagrange-Multiplier statistic for underidentification ${ }^{16}$ are small, indicating

\footnotetext{
${ }^{16}$ Jaeger, Ruist, and Stuhler (2018) recommend reporting the Kleibergen-Paap LM statistic in settings with multiple endogenous variables and multiple instruments where the instruments are potentially highly collinear. The Kleibergen-Paap LM statistic tests the null hypothesis that the structural equation is underidentified (i.e., that the rank condition fails), meaning that the correlation between the endogenous variables and the instruments is not statistically different from zero and thus the instrument is irrelevant. Note that since weak instruments can occur
} 
that this model is under-identified and suffers from weak instruments. The authors also recommend using a base year at least one decade before the earliest lag period, which in our context means excluding 1980 from the analysis. We do this in columns (3) and (4). The basic story is unchanged; there is inadequate power to separately identify the short- and medium-run impacts of immigration in this setting. Performing the same analysis on the age 80-plus sample (columns (5) through (8) of Table 6) and the 1980-2017 sample (Appendix Table 6) results in the same conclusion: because of persistence of immigrant inflows across places over time, it is impossible to distinguish between short- and medium-run impacts of immigration on the institutionalization of the elderly.

<PLACE TABLE 6 HERE>

A related critique of the shift-share instrument is that it is heavily influenced by base year immigrant shares. Commuting zones with many immigrants in 1970 could be on a different institutionalization trajectory for reasons unrelated to future immigrant inflows. To examine this possibility, we control for the interaction of initial foreign-born share and time trends in Table 7. Column (1) of Table 7 replicates the main result. Column (2) shows the effect of a linear time trend interacted with initial immigrant share, and column (3) allows the effect of initial immigration to vary non-linearly by year. Controlling for differential trends between places with more and fewer immigrants at baseline reduces the strength of the instruments, as is evident in the lower F-statistics, but does not reduce the magnitude of the key coefficient. Thus, while we cannot separate short- and medium-run impacts of immigration, we can rule out a simple differential trend story based on 1970 immigrant shares.

<PLACE TABLE 7 HERE $>$

even if the underidentification null hypothesis is rejected, the test for underidentification provides a lower hurdle than the test for weak instruments. 
In Table 7, we also look into potential impacts of regional trends. Predicted immigration inflows are concentrated in some regions more than others, so we control for region-specific time trends in column (4), with little change in the coefficient. In column (5) of Table 7, we do see meaningful reductions in the size of the coefficients when region*year effects are included as controls, perhaps because the variation is limited to within-region differences in predicted immigration. Nevertheless, the coefficients are statistically significant and suggest a 0.7-0.8 percentage point reduction in institutionalization associated with a 10 percentage point increase in immigrant share.

In column (6) we use state-specific linear trends, and in column (7) we incorporate state*year effects. After controlling for state*year effects, there is no statistically significant association and the instrument is weak, likely because there is inadequate variation in the shift-share instrument across CZs within the same state. Therefore, we cannot rule out the possibility that unobserved state-specific or locality-specific policy variation correlated with immigrant location patterns has a direct effect on institutionalization.

One form of policy variation that might be of particular concern relates to policies affecting the housing costs associated with living in the community. Immigration might also reduce housing costs by increasing the labor supply of construction workers or raise housing costs by raising demand; these costs may impact the ability for an individual to live in the community. Column (8) controls for the median rent for a two-bedroom home in a CZ and column (9) controls for median property tax and insurance payments for homeowners in the $\mathrm{CZ}$. Neither of these housing expense controls substantively impact the coefficient of interest, suggesting that any impact of immigration on housing costs is not driving the results.

In the remaining columns of Table (7), we perform some additional robustness checks. In column (10), we exclude all observations from California, the largest immigrant destination state. Dropping California attenuates the coefficient and weakens the instrument, but the estimate remains negative and statistically significant. In column (11), we try dropping all demographic 
controls, keeping CZ fixed effects and year fixed effects as the only controls in the regression. Compared to the baseline regression, this coefficient is smaller in magnitude and less precisely estimated, retaining only marginal significance. We add the control for age into column (12), without other demographic controls, which reduces the standard error relative to column (11) and increases the statistical significance.

Appendix Table 7 repeats the robustness checks in Table 7 for the age $80+$ sample as well as for the 1980-2017 samples for both age $65+$ and $80+$. The pattern of results is similar. The variation is driven mainly by regional differences in immigrant settlement patterns, and we cannot rule out the possibility state-specific policy decisions that are caused by or are contemporaneous with immigration inflows. Nevertheless, we conclude that the negative association between lesseducated immigrant share and institutionalization is robust, with 47 of 48 coefficients in Appendix Table 7 showing a negative point estimate.

\section{Mechanisms}

The analyses above suggest that immigrant presence in a local area is causally related to whether the elderly live at home or in an institution. We now consider one potential mechanism for this relationship, the local labor market. Specifically, we aggregate Census data on the working age (16-64) population to the CZ level in 1980, 1990, and 2000. We divide the sample by reported occupation in the following categories: nursing and health aides, registered nurses, licensed practical nurses, housekeepers and gardeners, construction workers, and all other occupations. Within the nursing and health aides category, we use reported industry to classify individuals as home-based aides, nursing-home based aides, and aides in other setting. This classification is imperfect due to changing definitions over time and should be viewed with caution.

The labor market analysis examines two measures of hourly wages, which are estimated using annual wage earnings divided by estimated weeks worked times usual hours worked per week, 
restricting to full-time (35-50 hours), full-year (50-52 weeks) workers. The first measure is the log of real median hourly wages of full-time, full-year workers, adjusted to 2005 dollars. The second measure is the median hourly wage in the occupation relative to those in the $\mathrm{CZ}$ as a whole.

We also consider several measures of labor supply. We use the log of the number of people employed in the occupation and the employment in the occupation relative to the working-age population in the CZ. In addition, we use the log of aggregate hours worked in the occupation and the share of total CZ hours worked in the occupation. Because the occupational categories are fairly narrow, there are some missing values.

Using the same instrumental variables strategy, we examine whether the less-educated foreignborn share affects these occupation-specific labor market outcomes. Regressions are at the CZyear level and are weighted by the working-age population. The results are shown in Table 8, with each cell representing the coefficient from a separate regression. As shown in the first two columns of the first row, there is a clear negative impact of immigration on the wages of nursing and health aides, overall and relative to other workers in the $\mathrm{CZ}$. The magnitude of the coefficient in the first column suggests that median wages for nursing and health aides would have been about 8 percent higher in the year 2000 if immigration had remained at 1980 levels. These occupations also witness an increased number of workers and increased number of aggregate hours. In separating by industry, it appears that home health aides are especially likely to see positive employment effects, and nursing home aides also experience effects depending on the specific measure. Licensed practical nurses have wage reductions but do not have employment increases, suggesting a reduction in labor demand. Registered nurses command higher wages and have, if anything, lower employment levels when immigration is higher.

\section{<PLACE TABLE 8 HERE>}

We also examine housekeepers and gardeners, as well as construction workers. These groups see negative wage impacts. The estimated effects on employment are mixed. Restricting to less- 
educated workers, we see that those in all other occupations have lower wages and higher levels of employment as a share of the population. There are no measurable wage impacts on other occupations when pooling all education groups.

In sum, it appears that local areas with more less-educated immigrant labor have cheaper access to nursing and health aides as well as other household services. It is important to note that we have not attempted to answer how immigrant inflows affect wages of U.S. natives, and the wage effects we see could be driven by compositional impacts. The positive employment effects for nursing and health aides are consistent with elderly individuals purchasing more of these services in home-based settings, and the relatively low cost of housekeeping, gardening, and construction services may facilitate elderly individuals' decision to remain living in the community.

There are other potential mechanisms for our main finding as well. As noted above, if immigration affects housing prices as has been suggested by Saiz (2007), we could see an indirect impact on institutionalization. The investigation in Table 7 does not provide support for this channel. Immigration could also affect wealth accumulation of the U.S.-born elderly, which we unfortunately cannot observe. However, the absence of systematic differential impacts by demographic group (Table 3 ) and the robustness to controls for lagged institutionalization (Table 5) casts doubt on this as a primary mechanism.

An alternative mechanism may be the spread of social norms from immigrants to natives. Immigrants are less likely to institutionalize their elderly, and this social norm may spread to the US-born when immigrants arrive in US communities. As shown in Table 3, we do not see significant differences in impacts across race/ethnicity groups or education groups and therefore do not have any evidence to support social norms as an explanation for the results. Indeed, recent work that finds that cultural norm transmission operates more from the host country to the home country than vice-versa (Rapoport, Sardoschau, \& Silve 2020). Nevertheless, it should be noted that our subgroup analysis lacks statistical power and we do not have information on social networks that would allow us to investigate this mechanism more fully. 


\section{Discussion and Conclusion}

The share of elderly in the U.S. is growing and is expected to continue to rise through 2030. Difficulties with mobility, cognition, and self-care rise steeply with age, meaning that there will be a larger share of the population in need of significant caregiving than the U.S. has witnessed in the past.

We describe two types of caregiving "technologies of production": labor intensive, with the elderly spread out geographically in private homes, or capital intensive, where the elderly live close together in purpose-built capital-intensive institutional environments. We posit that an abundance of less-educated labor that can substitute for the elderly individual's (or their family's) labor in home production, potentially shifting the choice of technology for elderly care-giving away from institutions.

In order to identify exogenous variation in the share of less-educated working-age individuals available, we implement an instrumental variables strategy. We use a widely-used instrument based on historical settlement patterns by country of origin interacted with national-level immigration levels. We then use the resulting prediction to instrument for the share lesseducated foreign-born in a commuting zone in a given year. Our estimates suggest that a 10 percentage point increase in the less-educated immigrant population share reduces the probability of the elderly living in an institutional setting by about 1.5 percentage points for those aged 65 and up and 3.8 percentage points for those aged 80 and up. This represents a 29 and 26 percent reduction in the probability of institutionalization, respectively. For the population age 65 and up, the results imply that institutionalization rates in 2000 would have been 0.5 percentage points (10 percent) lower if immigration had remained at 1980 levels. 
We also attempt to address the concern of selective migration of the U.S.-born elderly. We extend the instrument to incorporate historical migration patterns for elderly Americans by birth state. Accounting for selective migration of the elderly does not reduce the apparent effect of immigration-induced labor market changes on institutionalization. Similarly, controlling for cohort-level lagged institutionalization rates does not change the main result.

The analysis also considers the Jaeger et al. (2018) critique of shift share instruments. Using their suggested methodology, we are unable to distinguish between short- and medium-run impacts of immigration on institutionalization. We argue that the medium run is the appropriate reference period in this setting, but we lack the statistical power to separately identify the relevant time frame. We do, however, demonstrate that the results are not driven by differential secular trends in local areas that happened to have more immigrants in 1970.

We find support for one potential mechanism to explain the findings: wages of less-educated workers are negatively related to immigrant shares, and particularly in key occupations that are complements to aging in place such as health and nursing aides, housekeepers and gardeners. Shifts in the costs of services that are complementary to aging in place likely affect decision making. We do not find support for the notion that housing costs or social norms explain the effect of immigration on institutionalization, though more research is needed to rule these out as potentially relevant factors.

Given that the elderly report that they would prefer to avoid living in institutionalized settings, it is important to understand what may help them actualize their preferences. This study suggests that the supply of less-educated immigrant labor affects caregiving arrangements, and allows more older Americans to age in the community. 


\section{References}

Altonji, J. G., \& Card, D. (1991). The Effects of Immigration on the Labor Market Outcomes of Less-educated Natives. In J. M. Abowd \& R. B. Freeman (Eds.), Immigration, Trade, and the Labor Market (pp. 201-234). Chicago, IL: University of Chicago Press. http://www.nber.org/chapters/c11773

Andrews, I., Stock, J. H., \& Sun, L. (2019). Weak instruments in instrumental variables regression: Theory and practice. Annual Review of Economics, 11(1), 727-753. doi:10.1146/annurev-economics-080218-025643

Autor, D. H., \& Dorn, D. (2013). The growth of low-skill service jobs and the polarization of the US labor market. American Economic Review, 103(5), 1553-1597. doi:10.1257/aer.103.5.1553

Autor, D., Dorn, D., \& Hanson, G. (2019). When work disappears: Manufacturing decline and the falling marriage market value of young men. American Economic Review: Insights, 1(2), 161178. doi:10.1257/aeri.20180010

Bartel, A. P. (1989). Where do the new U.S. immigrants live? Journal of Labor Economics, 7(4), 371-391. doi:10.1086/298213

Binette, J., \& Vasold, K. (2018). 2018 Home and Community Preferences: A National Survey of Adults Age 18-plus. doi:10.26419/res.00231.001

Butcher, K. F., \& Piehl, A. M. (1998). Recent immigrants: Unexpected implications for crime and incarceration. Industrial and Labor Relations Review, 51(4), 654-679.

doi:10.1177/001979399805100406

Butcher, K.F., \& Watson, T. (2019). Immigration and tomorrow's elderly. Peterson 2050 project. Available at https://www.pgpf.org/us-2050/research-projects/Immigration-and-TomorrowsElderly.

Centers for Medicare \& Medicaid Services (CMS). (2020). National Health Expenditures 2019 Highlights. Retrieved from https://www.cms.gov/files/document/highlights.pdf.

Clemens, M. A., Lewis, E. G., \& Postel, H. M. (2018). Immigration restrictions as active labor market policy: Evidence from the Mexican Bracero Exclusion. American Economic Review, 108(6), 1468-1487. doi:10.1257/aer.20170765

Cortes, P. (2008). The effect of low-skilled immigration on U.S. prices: Evidence from CPI data. Journal of Political Economy, 116(3), 381-422. doi:10.1086/589756 
Cortes, P., \& Pan, J. (2015). The relative quality of foreign-educated nurses in the United States. Journal of Human Resources, 50(4), 1009-1050. doi:10.3368/jhr.50.4.1009

Cortés, P., \& Tessada, J. (2011). Low-skilled immigration and the labor supply of highly skilled women. American Economic Journal: Applied Economics, 3(3), 88-123. doi:10.1257/app.3.3.88

East, Chloe, and Andrea Velasquez, 2018. "Unintended Consequences of Immigration Enforcement: Household Services and High-Skilled Women's Work," IZA DP No. 12029.

Engelhardt, G. V., Gruber, J., \& Perry, C. D. (2005). Social Security and elderly living arrangements. Journal of Human Resources, 40(2), 354-372. doi:10.3368/jhr.xl.2.354

Eriksen, M. D., Greenhalgh-Stanley, N., \& Engelhardt, G. V. (2015). Home safety, accessibility, and Elderly Health: Evidence from falls. Journal of Urban Economics, 87, 14-24. doi:10.1016/j.jue.2015.02.003

Frimmel, W., Halla, M., Paetzold, J., \& Schmieder, J. (2020). Health of elderly parents, their children's labor supply, and the role of migrant care workers. SSRN Electronic Journal. doi:10.2139/ssrn.3706014

Furtado, D., \& Ortega, F. (2020). Do immigrant flows improve quality of care in nursing homes? IZA Discussion Paper Series, No. 13552. https://docs.iza.org/dp13552.pdf

Grabowski, David, Jonathan Gruber, and Brian McGarry, 2020. "Immigration, the Labor Market, and the Quality of Long-Term Care," Work in progress presented at NBER summer institute, 2020.

Jaeger, D., Ruist, J., \& Stuhler, J. (2018). Shift-share instruments and the impact of immigration. doi:10.3386/w24285

Kleibergen, F., \& Paap, R. (2006). Generalized reduced rank tests using the singular value decomposition. Journal of Econometrics, 133(1), 97-126. doi:10.1016/j.jeconom.2005.02.011

Lewis, E. (2011). Immigration, skill mix, and capital skill complementarity. The Quarterly Journal of Economics, 126(2), 1029-1069. doi:10.1093/qje/qjr011

Mommaerts, C. (2018). Are Coresidence and nursing homes substitutes? evidence from Medicaid spend-down provisions. Journal of Health Economics, 59, 125-138. doi:10.1016/j.jhealeco.2018.04.003

Montiel Olea, J. L., \& Pflueger, C. (2013). A robust test for weak instruments. Journal of Business \& Economic Statistics, 31(3), 358-369. doi:10.1080/00401706.2013.806694

Miller, D. L., Page, M. E., Stevens, A. H., \& Filipski, M. (2009). Why are recessions good for your health? American Economic Review, 99(2), 122-127. doi:10.1257/aer.99.2.122 
Rapoport, H., Sardoschau, S., \& Silve, A. (2020) Migration and cultural change. CESifo Working Papers, No. 8547. https://ssrn.com/abstract=3689469

Ruggles, S., Flood, S., Goeken, R., Grover, J., Meyer E., Pacas J., \& Sobek, M. (2019). IPUMS USA: Version 9.0 [dataset]. IPUMS.

Saiz, A. (2007). Immigration and Housing Rents in American cities. Journal of Urban Economics, 61(2), 345-371. doi:10.1016/j.jue.2006.07.004

Staiger, D., \& Stock, J. H. (1997). Instrumental variables regression with weak instruments.

Econometrica, 65(3), 557-586. doi:10.2307/2171753

Tolbert, C.T., Sizer, M. (1996). U.S. commuting zones and labor market areas: a 1990 update. United States Department of Agriculture Economic Research Service. doi:

10.22004/ag.econ.278812

U.S. Census Bureau, Population Division, "2017 National Population Projections Tables: Table 2", https://www.census.gov/data/tables/2017/demo/popproj/2017-summary-table

Van Houtven, C. H., Konetzka, R. T., Taggert, E., \& Coe, N. B. (2020). Informal and formal home care for older adults with disabilities increased, 2004-16. Health Affairs, 39(8), 1297-1301. doi:10.1377/hlthaff.2019.01800

Yogo, M., \& Stock, J. H. (2005). Identification and inference for econometric models: Essays in honor of Thomas Rothenberg (pp. 80-108) (D. W. Andrews, Ed.) (J. H. Stock, Ed.). Cambridge, UK: Cambridge University Press. 


\section{Figures}

Figure 1: Share Disabled by Age and Type of Disability.

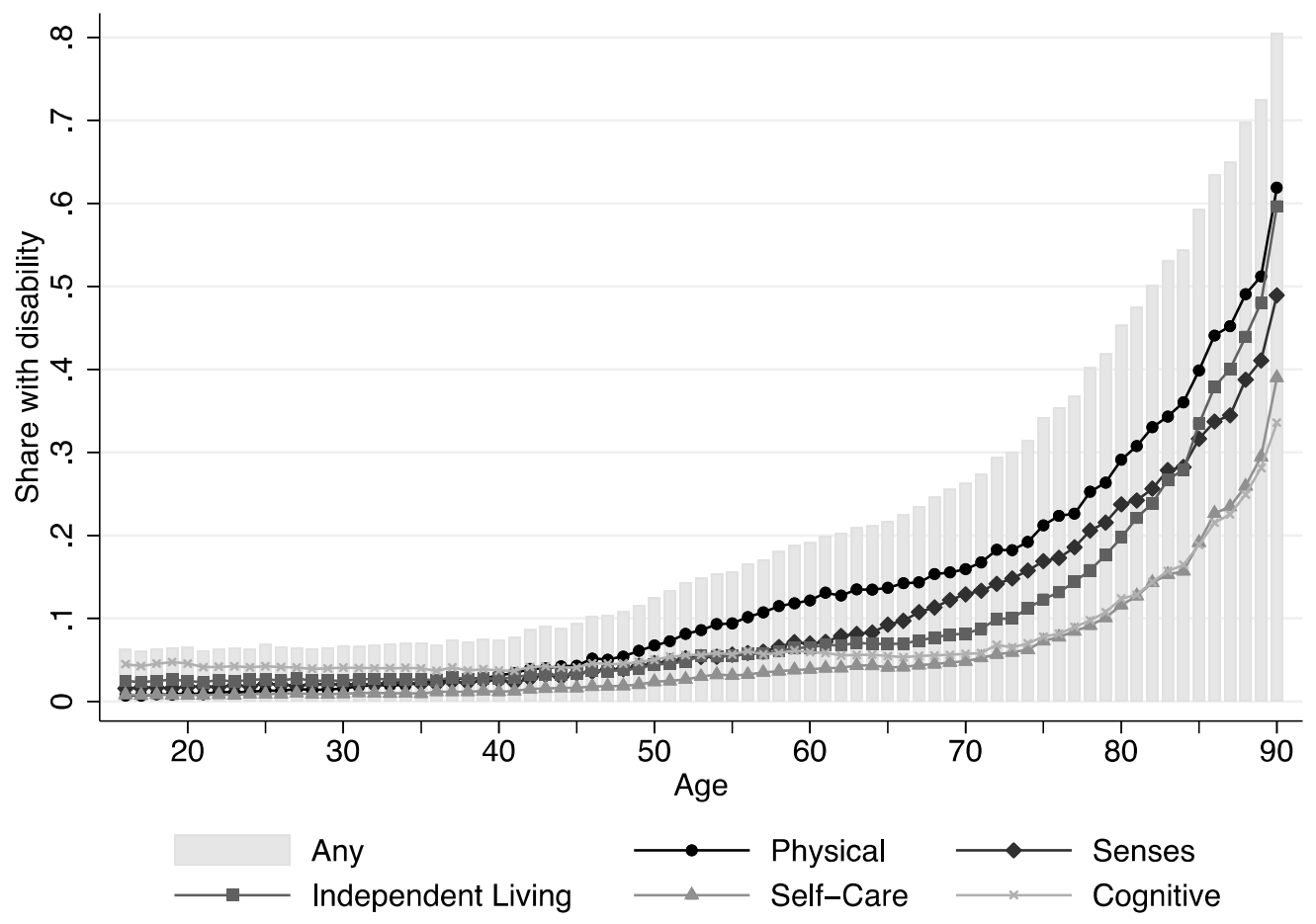

Source: 2017 American Community Survey.

Notes: Figure depicts the share of all individuals in the U.S. (native and foreign-born) at each age who reported any or a particular disability. The right-most data point in each series combines those ages 90 and older due to top-coding in the data. 
Figure 2: Share Institutionalized by Age and Year.

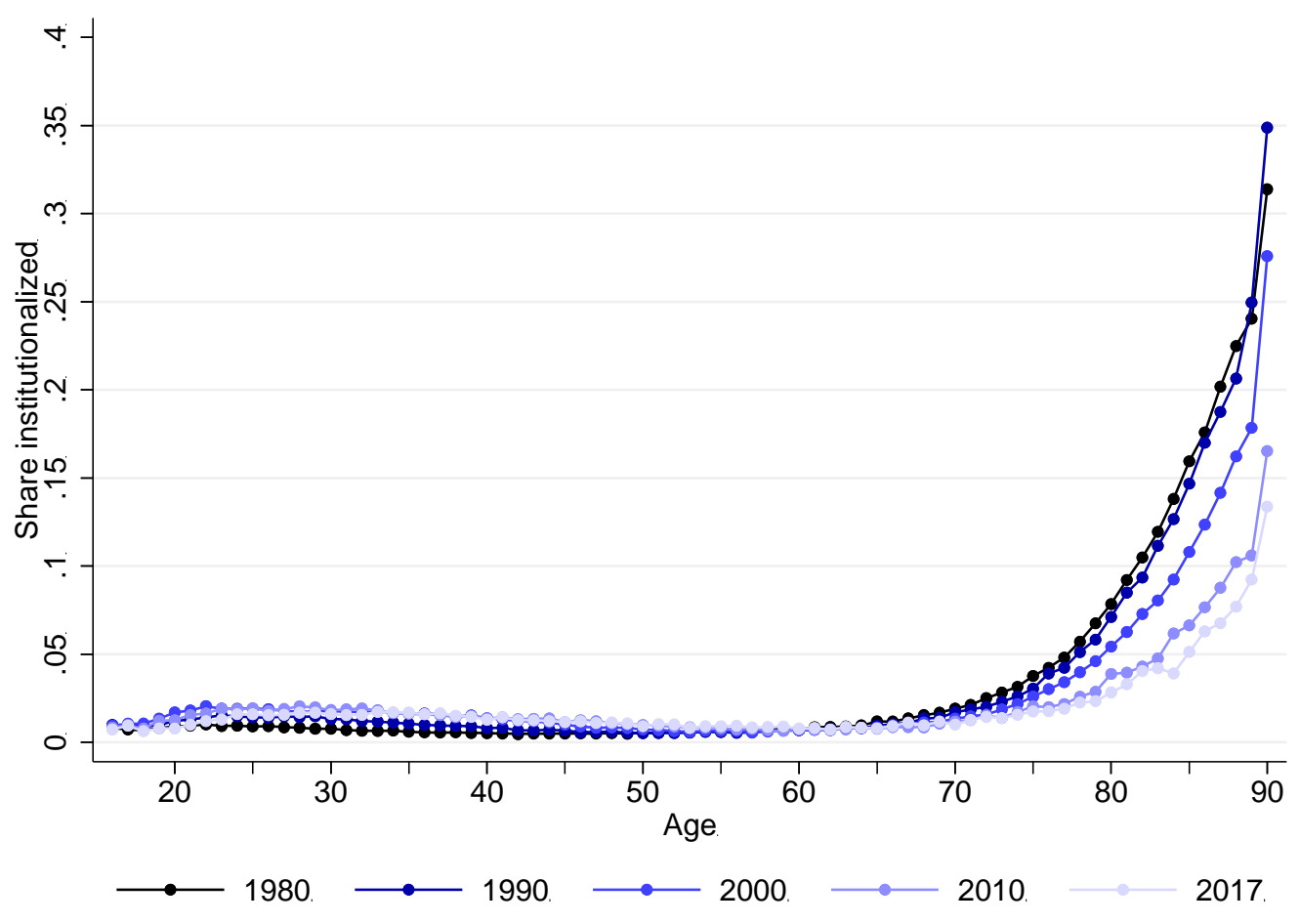

Source: 1980, 1990, and 2000 Census, 2010 and 2017 American Community Survey.

Notes: Figure depicts the share of all individuals in the U.S. (native and foreign-born) at each age who live in an institution. The right-most data point in each series combines those ages 90 and older due to top-coding in the data. 
Figure 3. Share of Foreign-Born from a Country Group in each CZ in 1970.

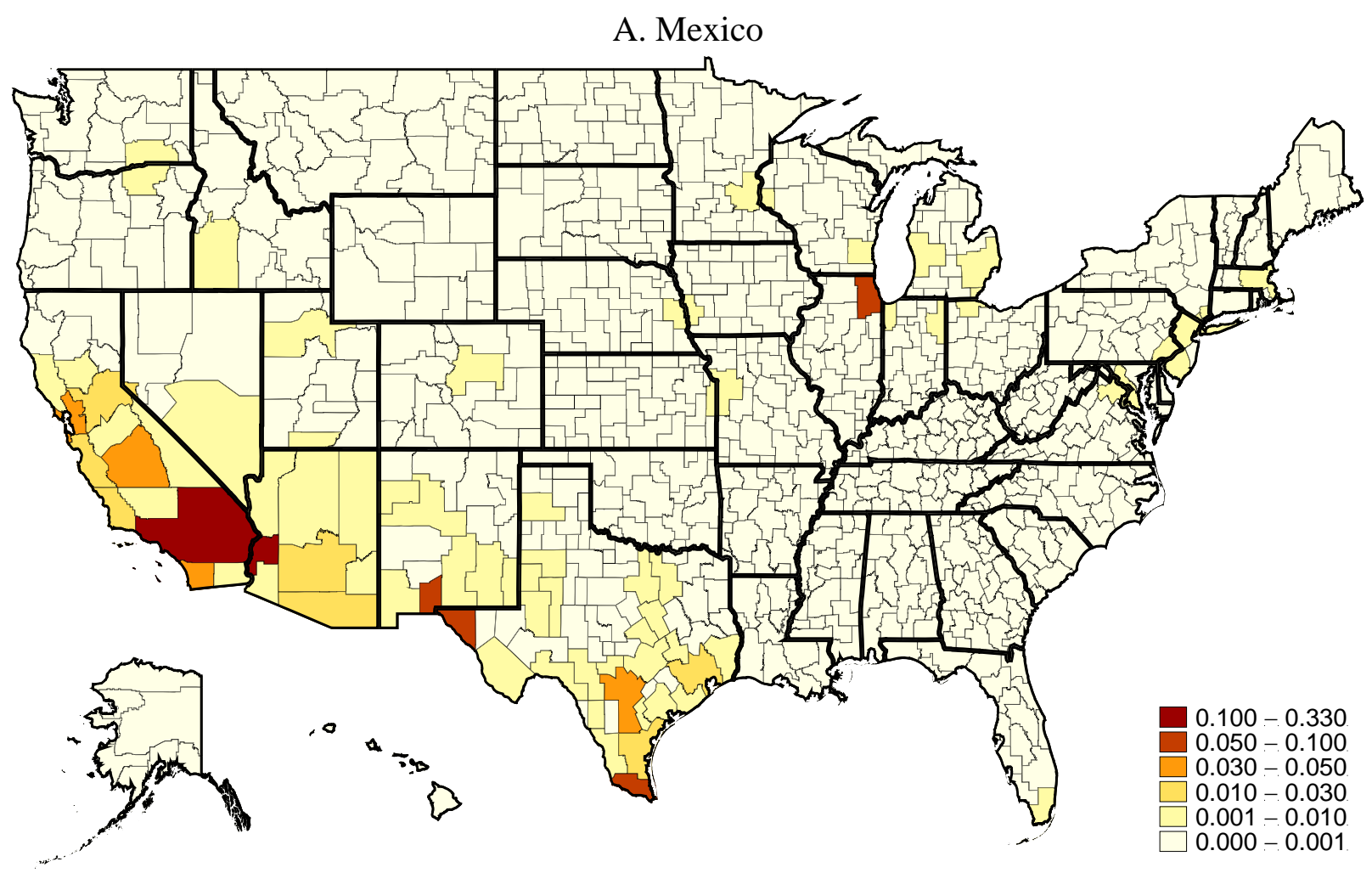

B. China

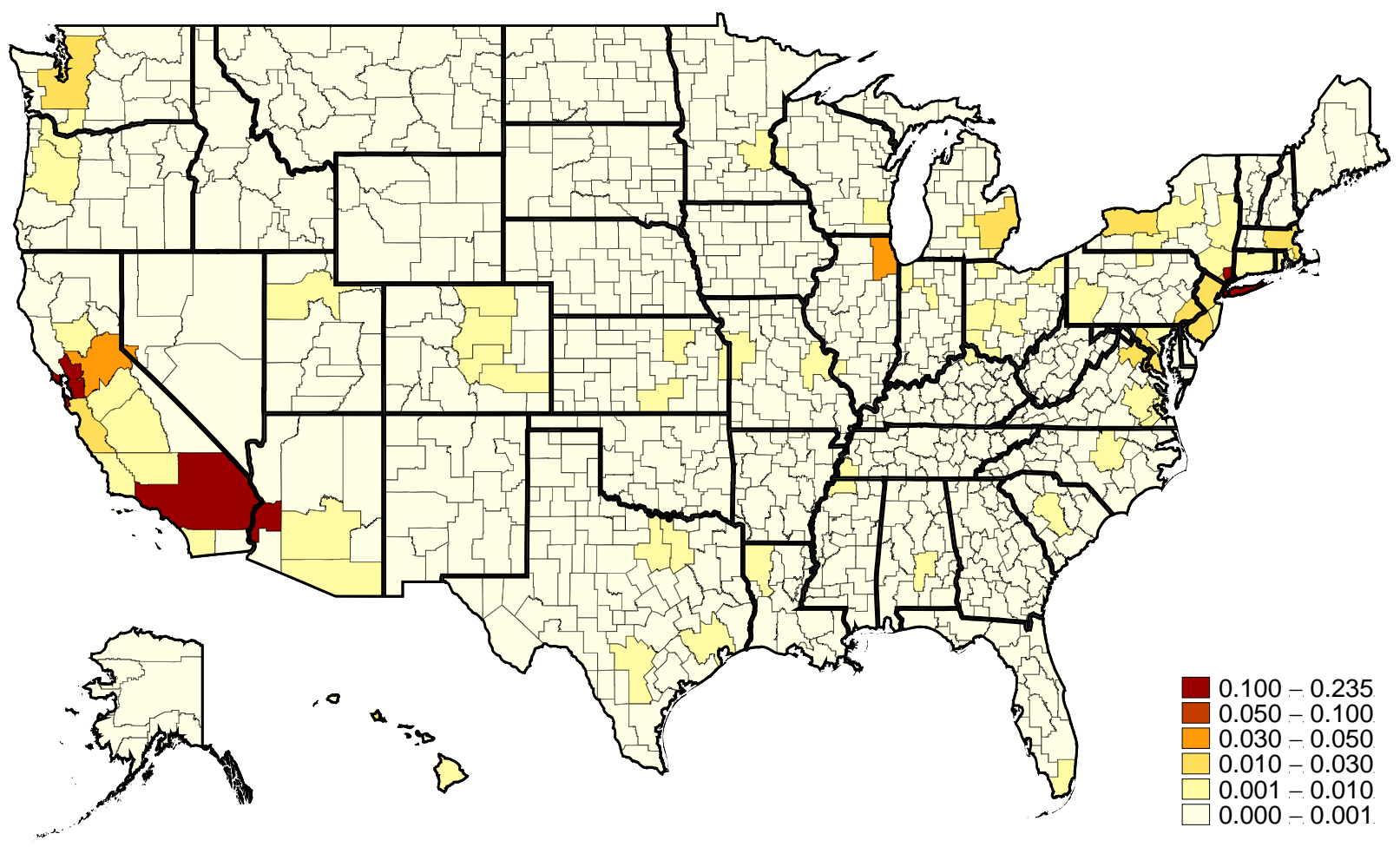


C. Italy

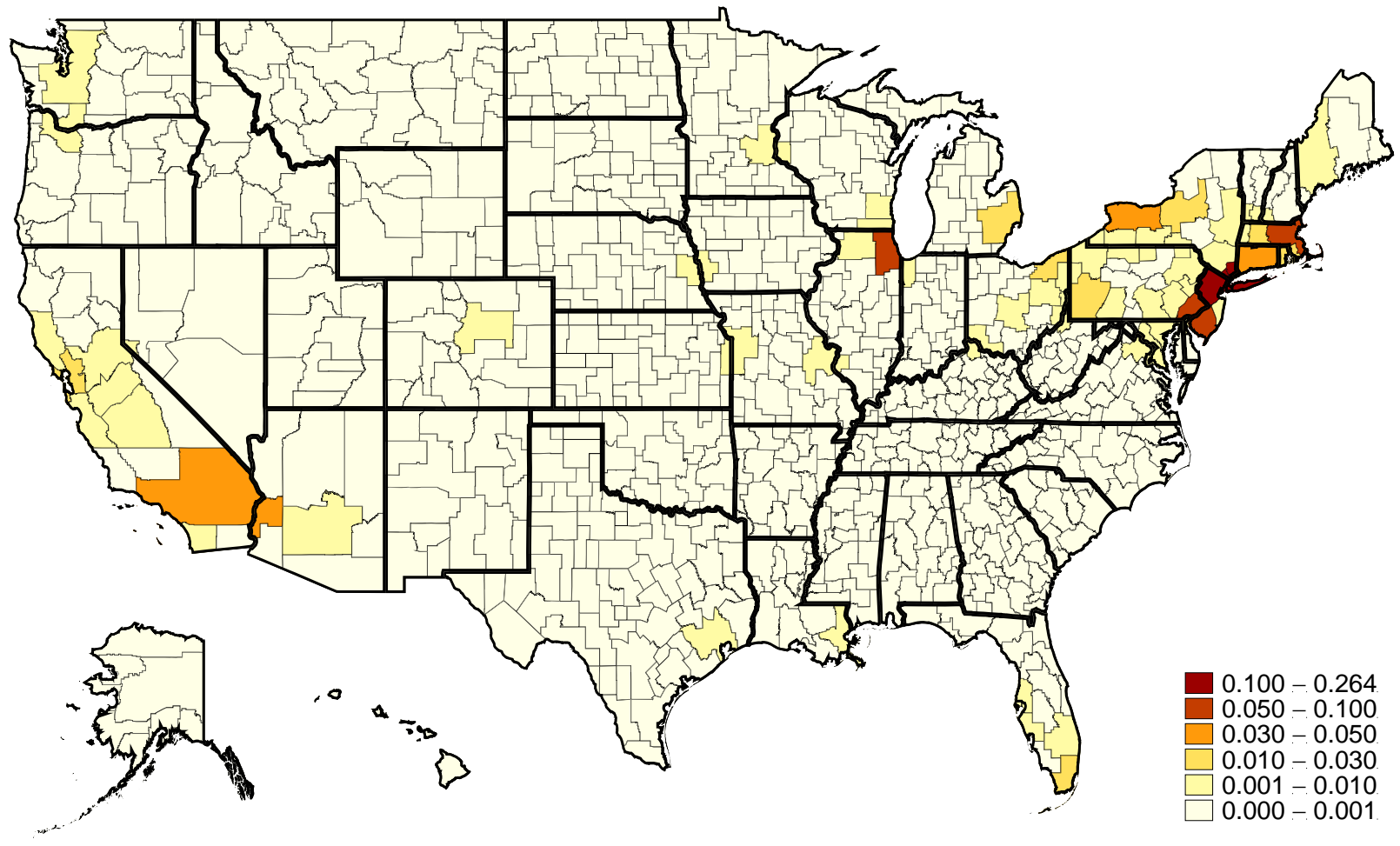

Source: 1970 Census

Notes: Figure depicts the share of foreign-born individuals from a specific country group (Mexico in Panel A, China in Panel B, and Italy in Panel C) that reside in each CZ in 1970. CZ boundaries are given by the thin black lines, while state boundaries are emphasized in thick black lines. Bins are consistent across all panels. 
Figure 4. Predicted Change in Share Less-Educated Immigrant, 1980-2000.

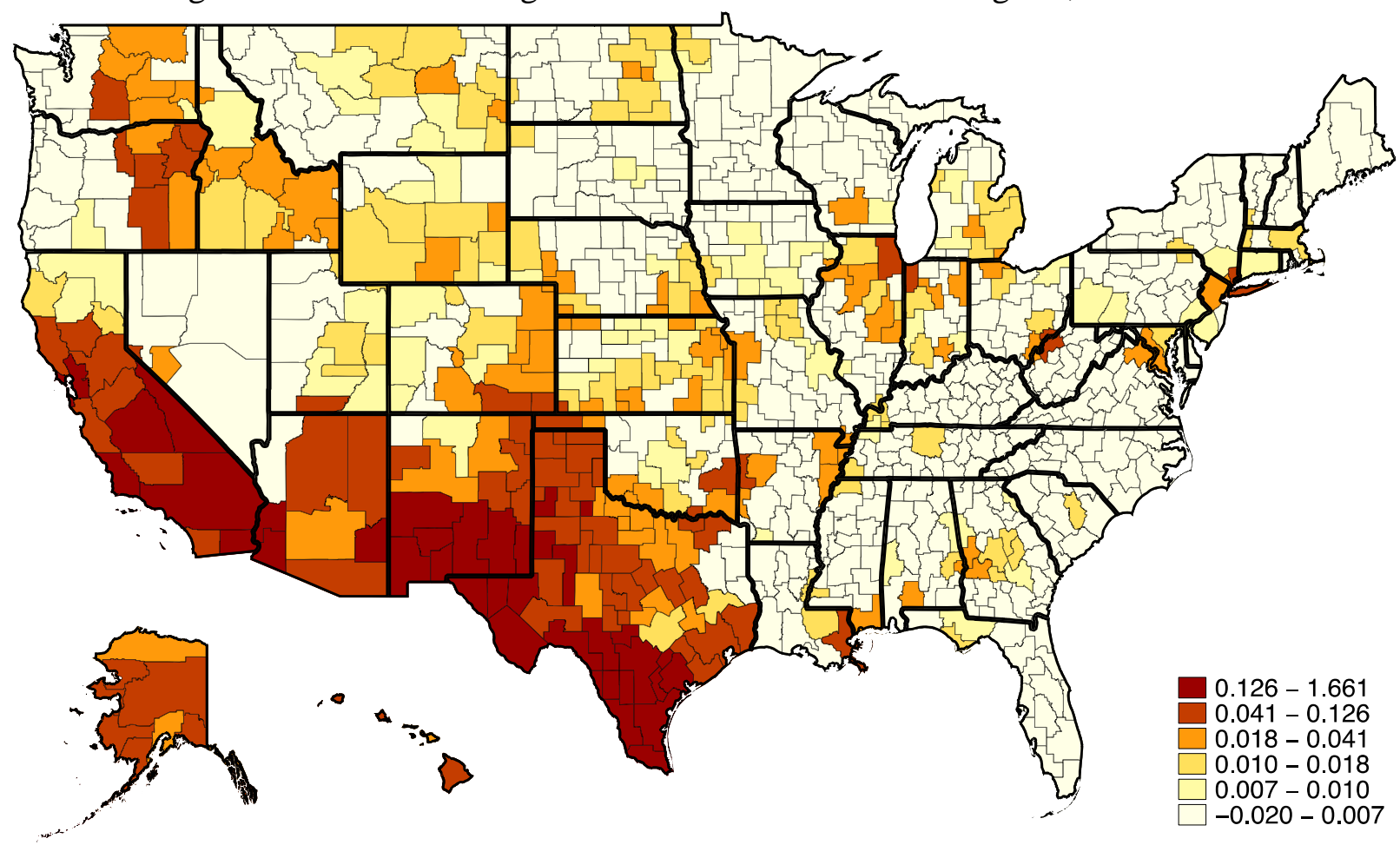

Source: 1970-2000 Census

Notes: Figure depicts the predicted change in the share of individuals in each CZ that is foreignborn and less-educated, from 1980 to 2000. CZ boundaries are given by the thin black lines, while state boundaries are emphasized in thick black lines. Bin upper cutoffs are equal to the 50th, 60th, 70th, 80th, 90th, and 100th percentiles of the CZ-level change, weighted by the mean elderly population in the CZ across 1980-2000. 
Figure 5. Actual Change in Share Less-Educated Immigrant, 1980-2000.

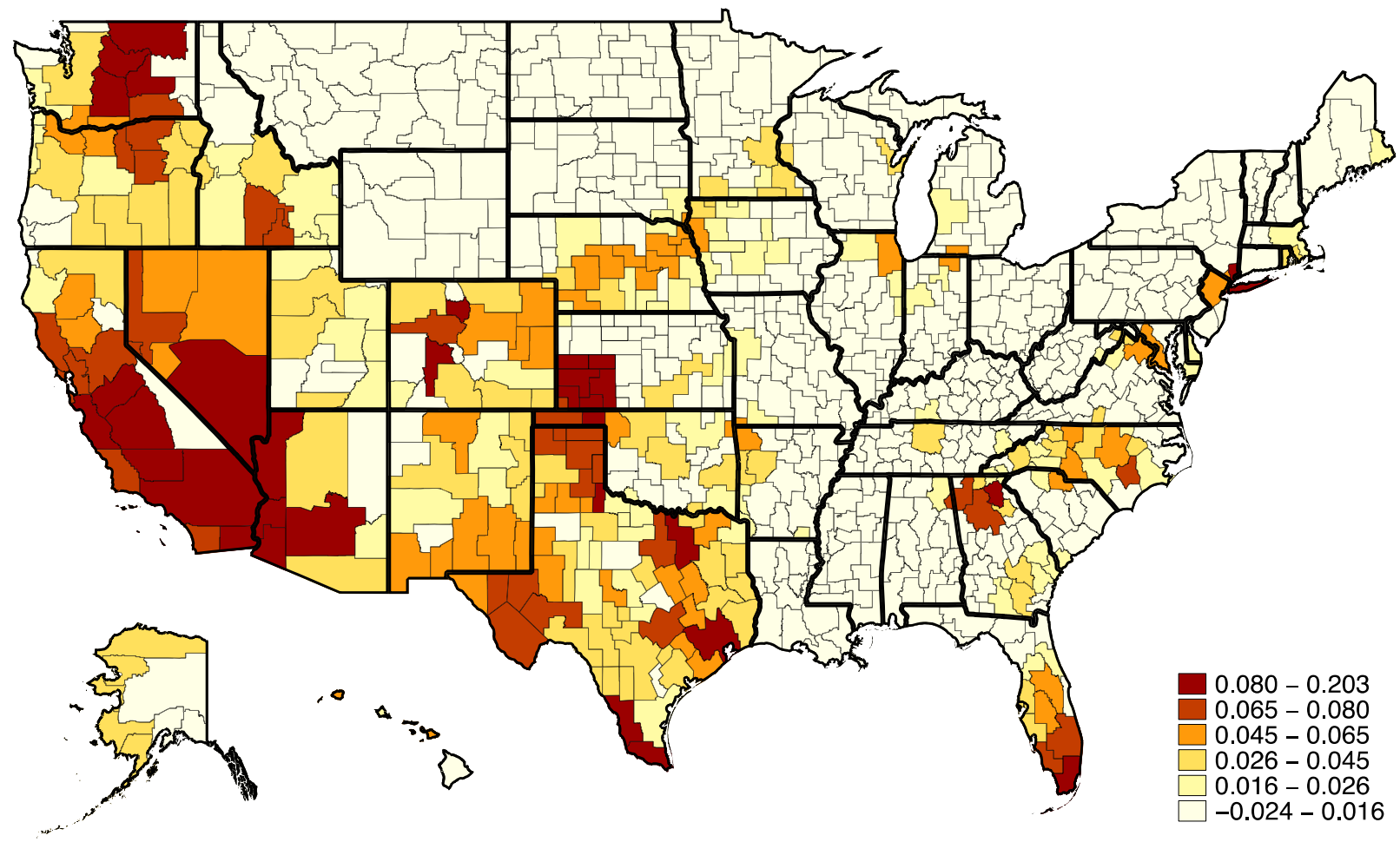

Source: 1970-2000 Census

Notes: Figure depicts the observed change in the share of individuals in each $\mathrm{CZ}$ that is foreignborn and less-educated, from 1980 to 2000 . CZ boundaries are given by the thin black lines, while state boundaries are emphasized in thick black lines. Bin upper cutoffs are equal to the 50th, 60th, 70th, 80th, 90th, and 100th percentiles of the CZ-level change, weighted by the mean elderly population in the CZ across 1980-2000. 


\section{Appendix Figures}

Appendix Figure 1. Share with Difficulties and Helpers by Age.

1A. Share with ADL Difficulty and with ADL Helpers

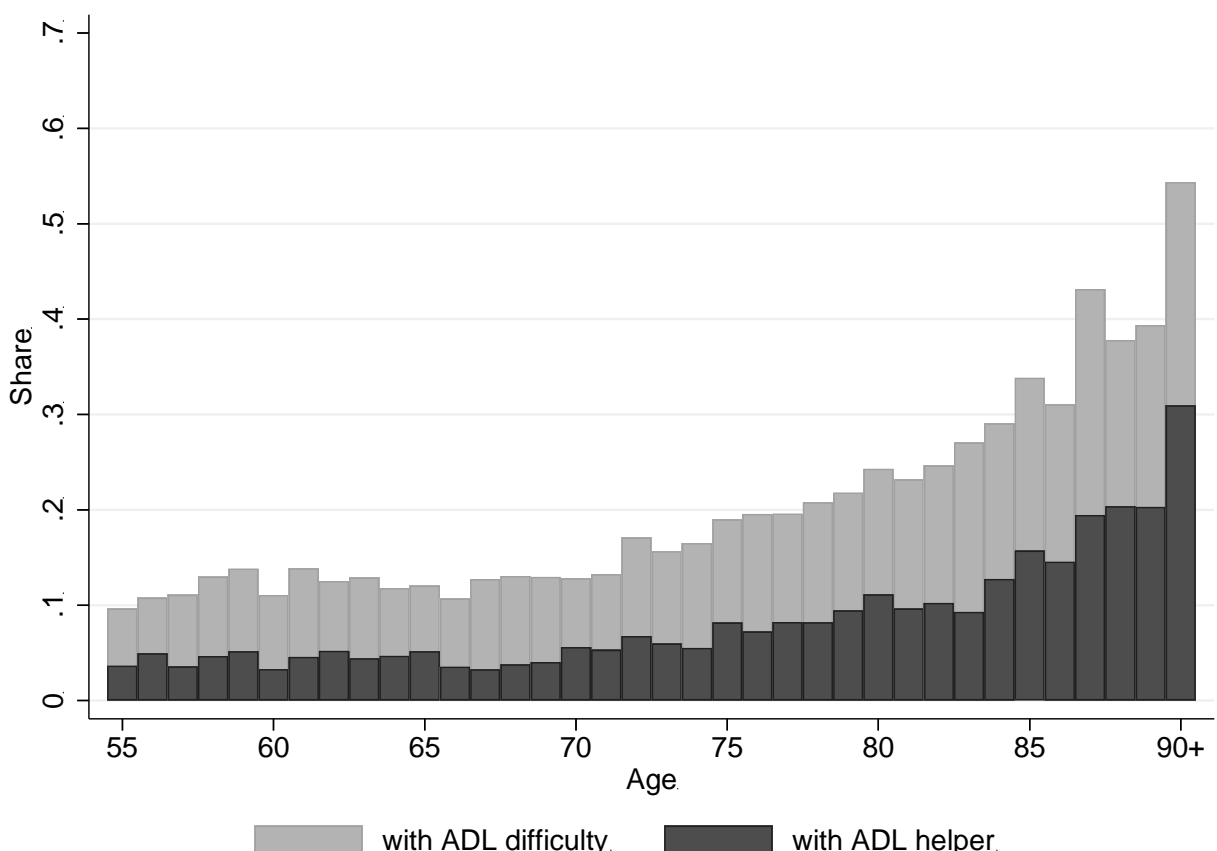

1B. Share with IADL Difficulty and with IADL Helpers

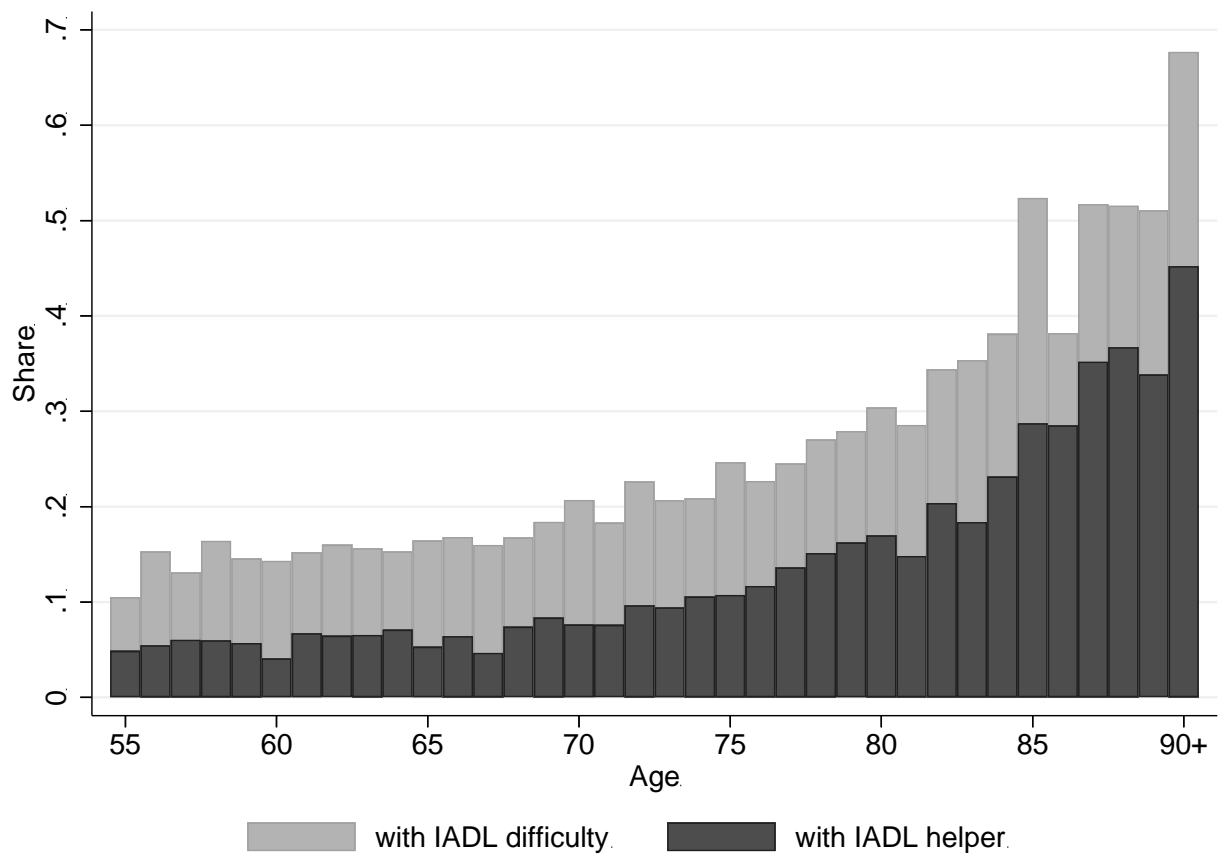


1C. Share with “Other Help” with Yard or Home

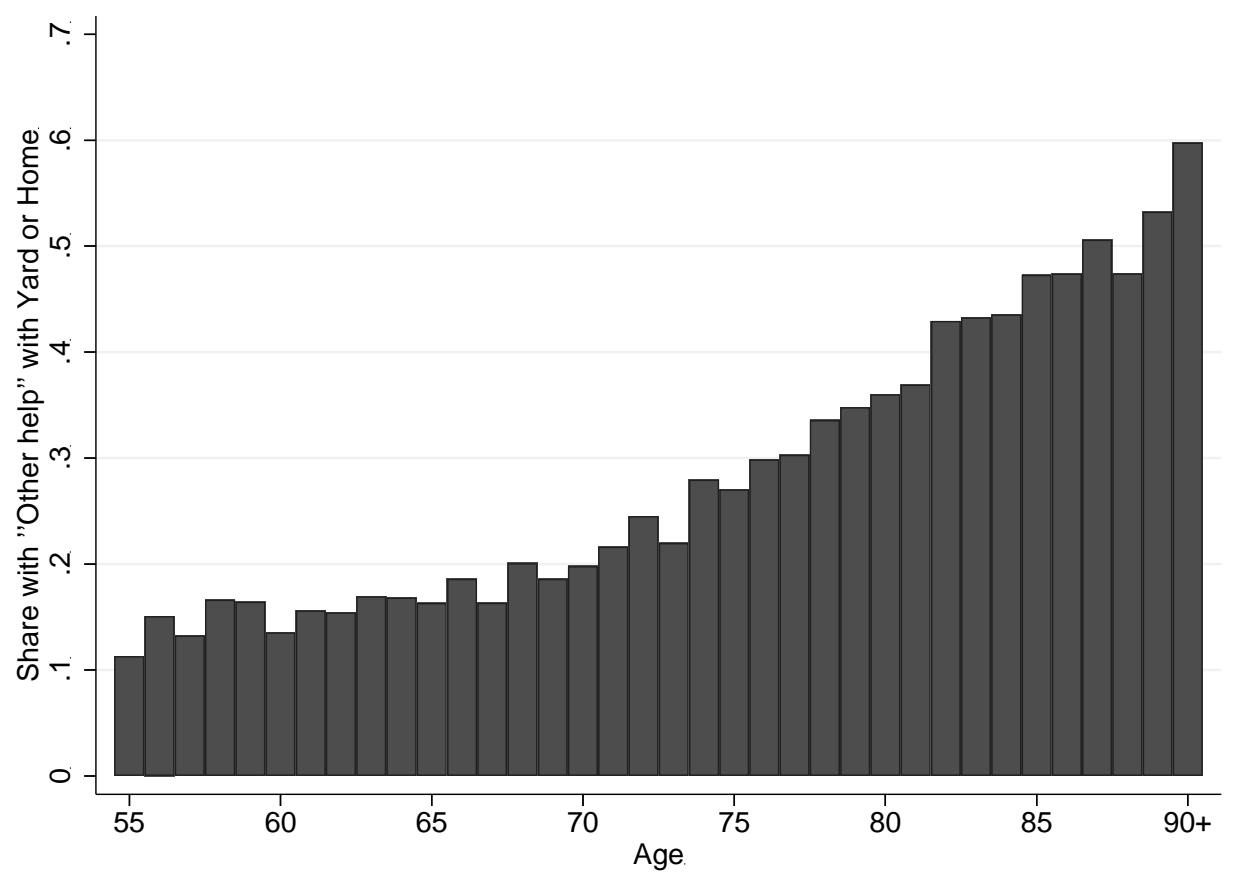

Source: 2002 and 2004 Health and Retirement Study.

Note: An individual is classified as having a difficulty with ADLs if they report having any difficulties with either dressing, walking, bathing, eating, getting in or out of bed, or using the toilet. An individual is classified as having a difficulty with IADLs if they report having any difficulties with either preparing a hot meal, shopping for groceries, making phone calls, taking medications, or managing money. Sample includes the native born aged 55 and above, with those aged 90 and above recorded as age $90+$. 
Appendix Figure 2. Foreign-Born Share in Key Occupations.

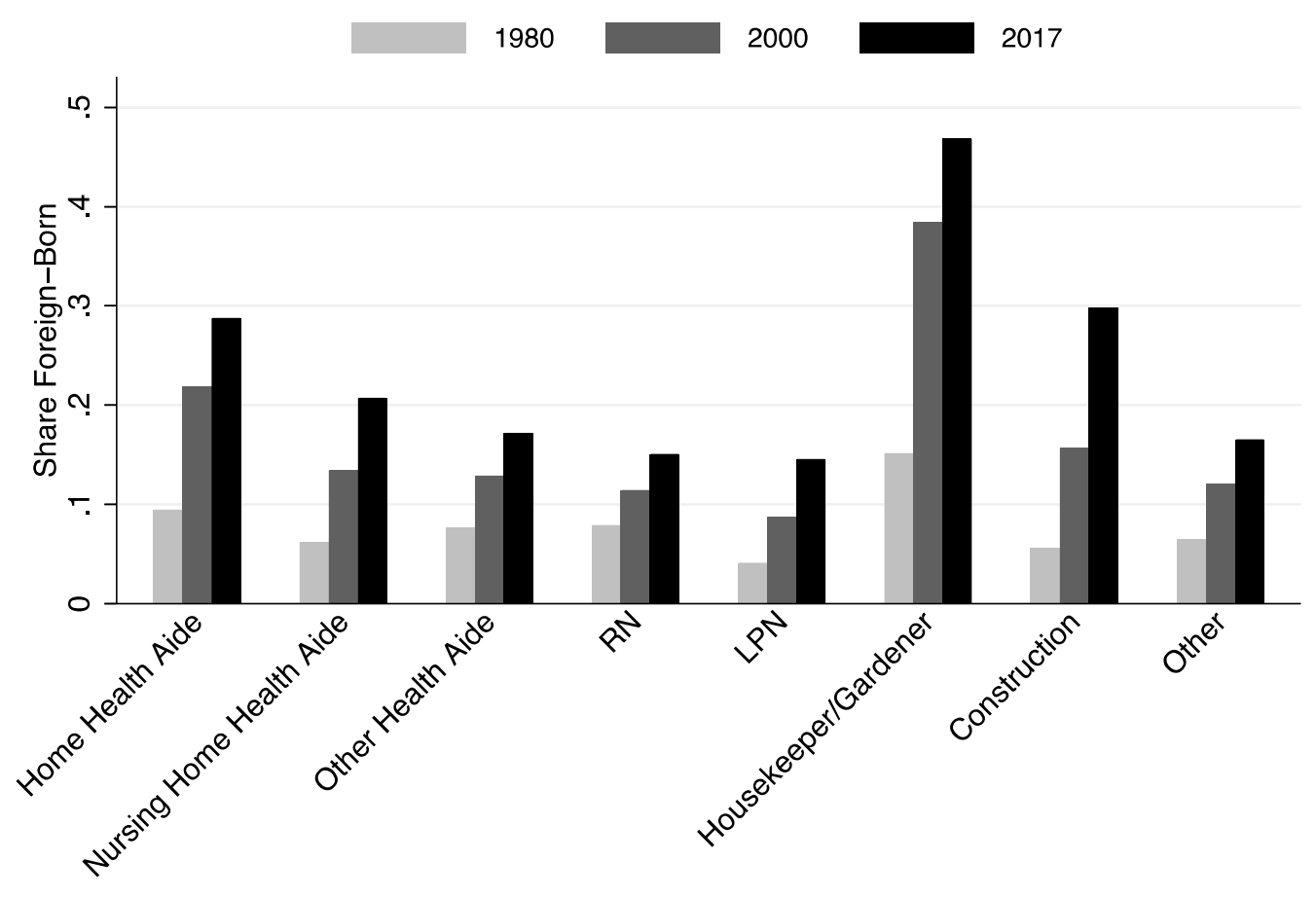

Source: 1980 and 2000 Census, 2017 American Community Survey.

Notes: Figure depicts the share of workers in each occupation that are foreign-born. 
Table 1. Summary Statistics for Key Variables by Year

\begin{tabular}{|c|c|c|c|c|c|}
\hline & \multicolumn{5}{|c|}{ Year } \\
\hline & 1980 & 1990 & 2000 & 2010 & 2017 \\
\hline \multicolumn{6}{|l|}{ Institutionalized } \\
\hline Mean & 0.052 & 0.053 & 0.050 & 0.034 & 0.028 \\
\hline Mean (Age 80+ Sample) & 0.165 & 0.162 & 0.129 & 0.083 & 0.071 \\
\hline \multicolumn{6}{|l|}{ Share Less-Educated Immigrant in CZ } \\
\hline Mean & 0.039 & 0.047 & 0.071 & 0.076 & 0.073 \\
\hline S.D. & 0.044 & 0.060 & 0.074 & 0.065 & 0.057 \\
\hline Min & 0.002 & 0.001 & 0.002 & 0.001 & 0.000 \\
\hline Max & 0.221 & 0.283 & 0.314 & 0.278 & 0.262 \\
\hline \multicolumn{6}{|c|}{ Predicted Share Less-Educated Immigrant in CZ } \\
\hline Mean & 0.039 & 0.048 & 0.070 & 0.071 & 0.067 \\
\hline S.D. & 0.043 & 0.059 & 0.099 & 0.106 & 0.098 \\
\hline Min & 0.001 & 0.001 & 0.001 & 0.000 & 0.000 \\
\hline Max & 0.453 & 0.868 & 2.114 & 2.584 & 2.171 \\
\hline \multicolumn{6}{|c|}{ Predicted Share Less-Educated Immigrant in CZ (Alternative) } \\
\hline Mean & 0.039 & 0.049 & 0.075 & 0.083 & 0.083 \\
\hline S.D. & 0.021 & 0.027 & 0.046 & 0.054 & 0.054 \\
\hline Min & 0.015 & 0.017 & 0.023 & 0.024 & 0.025 \\
\hline Max & 0.126 & 0.156 & 0.233 & 0.261 & 0.245 \\
\hline \multicolumn{6}{|c|}{ Wage of Less-Educated Workers Relative to Median in CZ } \\
\hline Mean & 0.908 & 0.851 & 0.850 & 0.796 & 0.786 \\
\hline S.D. & 0.040 & 0.052 & 0.048 & 0.065 & 0.068 \\
\hline Min & 0.816 & 0.682 & 0.700 & 0.594 & 0.593 \\
\hline Max & 1.028 & 1.000 & 0.962 & 1.000 & 1.000 \\
\hline \multicolumn{6}{|c|}{ Share of Hours Worked by Less Educated in CZ } \\
\hline Mean & 0.626 & 0.465 & 0.492 & 0.418 & 0.395 \\
\hline S.D. & 0.075 & 0.083 & 0.078 & 0.072 & 0.071 \\
\hline Min & 0.422 & 0.281 & 0.331 & 0.273 & 0.257 \\
\hline Max & 0.838 & 0.742 & 0.742 & 0.674 & 0.632 \\
\hline
\end{tabular}

Note: Weighted sample statistics for U.S. born elderly individuals ages 65+ except where otherwise noted. 
Table 2. Main Results

Panel A. OLS Relationship Between Fraction Working-Age Population Less-Educated Foreign-Born and Institutionalization of Elderly

\begin{tabular}{|c|c|c|c|c|c|c|c|c|}
\hline Dependent Variable: Institutionalized & $\begin{array}{c}1) \\
\text { Preferred Spec } \\
1980-2000\end{array}$ & $\begin{array}{c}(2) \\
\text { long difference } \\
1980-2000\end{array}$ & $\begin{array}{c}(3) \\
1980,1990,2000, \\
2010 \text { and } 2017\end{array}$ & $\begin{array}{c}(4) \\
\text { long difference } \\
1980-2017\end{array}$ & $\begin{array}{c}(5) \\
1980-1990\end{array}$ & $\begin{array}{c}(6) \\
1990-2000\end{array}$ & $\begin{array}{c}\text { (7) } \\
2000-2010\end{array}$ & $\begin{array}{c}\text { (8) } \\
\text { 2010-2017 }\end{array}$ \\
\hline Share Less-Educated Immigrant & $\begin{array}{c}-0.076 * * * \\
(0.019)\end{array}$ & $\begin{array}{c}-0.082^{* * *} \\
(0.021)\end{array}$ & $\begin{array}{c}-0.056^{* * *} \\
(0.012)\end{array}$ & $\begin{array}{c}-0.053^{* *} \\
(0.024)\end{array}$ & $\begin{array}{c}-0.074^{* * *} \\
(0.023)\end{array}$ & $\begin{array}{c}-0.064^{* *} \\
(0.026)\end{array}$ & $\begin{array}{l}-0.016 \\
(0.027)\end{array}$ & $\begin{array}{c}-0.022 \\
(0.041)\end{array}$ \\
\hline Number of Observations & $7,286,430$ & $4,684,249$ & $9,549,816$ & $3,480,364$ & $4,523,929$ & $5,364,682$ & $3,467,271$ & $2,263,386$ \\
\hline Number of Unique Observations & $4,294,262$ & $3,594,987$ & $8,527,375$ & $2,456,800$ & $2,621,023$ & $3,172,886$ & $3,197,728$ & $1,239,822$ \\
\hline R-squared & 0.102 & 0.095 & 0.087 & 0.081 & 0.115 & 0.103 & 0.080 & 0.058 \\
\hline Mean of Institutionalized & 0.0515 & 0.0509 & 0.0414 & 0.0362 & 0.0525 & 0.0512 & 0.0417 & 0.0308 \\
\hline
\end{tabular}

Panel B. First Stage

\begin{tabular}{|c|c|c|c|c|c|c|c|c|}
\hline $\begin{array}{l}\text { Dependent Variable: Share Working-Age } \\
\text { Population Less-Educated Immigrant }\end{array}$ & $\begin{array}{l}\text { preferred spec } 1980 . \\
2000 \\
\end{array}$ & $\begin{array}{c}\text { long difference } \\
1980-2000\end{array}$ & $\begin{array}{c}1980,1990,2000 \\
2010 \text { and } 2017\end{array}$ & $\begin{array}{c}\text { long difference } \\
1980-2017 \\
\end{array}$ & $1980-1990$ & $1990-2000$ & $2000-2010$ & 2010-2017 \\
\hline Predicted Share Less-Educated Immigrant & $\begin{array}{c}0.324^{* * *} \\
(0.061)\end{array}$ & $\begin{array}{c}0.366^{* * *} \\
(0.075)\end{array}$ & $\begin{array}{c}0.131^{* * *} \\
(0.022)\end{array}$ & $\begin{array}{c}0.099^{* * *} \\
(0.024)\end{array}$ & $\begin{array}{c}0.561^{* * *} \\
(0.204)\end{array}$ & $\begin{array}{c}0.226 * * * \\
(0.040)\end{array}$ & $\begin{array}{l}-0.393^{*} \\
(0.230)\end{array}$ & $\begin{array}{c}0.454^{* * *} \\
(0.161)\end{array}$ \\
\hline
\end{tabular}

Panel C. Instrumental Variables Analysis

\begin{tabular}{|c|c|c|c|c|c|c|c|c|}
\hline Dependent Variable: Institutionalized & $\begin{array}{c}\text { preferred spec } 1980 . \\
2000\end{array}$ & $\begin{array}{l}\text { long difference } \\
1980-2000\end{array}$ & $\begin{array}{l}1980,1990,2000 \\
2010 \text { and } 2017\end{array}$ & $\begin{array}{l}\text { long difference } \\
1980-2017\end{array}$ & $1980-1990$ & $1990-2000$ & $2000-2010$ & 2010-2017 \\
\hline $\begin{array}{l}\text { Share Less-Educated Immigrant } \\
\text { (Instrumented with Predicted Share) }\end{array}$ & $\begin{array}{c}-0.151^{* * *} \\
(0.027)\end{array}$ & $\begin{array}{c}-0.148^{* * *} \\
(0.022)\end{array}$ & $\begin{array}{c}-0.310^{* * *} \\
(0.113)\end{array}$ & $\begin{array}{l}-0.328^{*} \\
(0.181)\end{array}$ & $\begin{array}{c}-0.145^{* * *} \\
(0.055)\end{array}$ & $\begin{array}{c}-0.159 * * \\
(0.077)\end{array}$ & $\begin{array}{l}0.224 \\
(0.194)\end{array}$ & $\begin{array}{l}-0.106 \\
(0.104)\end{array}$ \\
\hline F-statistic for weak instruments & 28.31 & 23.91 & 35.01 & 17.35 & 7.530 & 31.97 & 2.926 & 7.991 \\
\hline
\end{tabular}

Robust standard errors in parentheses clustered on $\mathrm{CZ}$.

Controls include $\mathrm{CZ}$, year*age* ${ }^{*}$ ace f.e., bpl*race f.e., gender*marital status f.e., and education in 4 categories.

${ }^{* * *} p<0.01,{ }^{* *} p<0.05,{ }^{*} p<0.1$ 
Table 3. Subgroup Analysis

Panel A. Instrumental Variables Analysis - Ages 65+ (1980-2000)

\begin{tabular}{|c|c|c|c|c|c|c|c|c|}
\hline & & Non-Hispanic & Non-Hispanic & & & & & \\
\hline Dependent Variable: Institutionalized & All & White & Black & Hispanic & No College & Some College + & Female & Male \\
\hline Share Less-Educated Immigrant & $-0.151 * * *$ & $-0.160 * * *$ & $-0.108^{* *}$ & -0.562 & $-0.137^{* * *}$ & $-0.133 * * *$ & $-0.183^{* * *}$ & $-0.090 * * *$ \\
\hline (Instrumented with Predicted Share) & $(0.027)$ & $(0.026)$ & $(0.050)$ & $(0.403)$ & $(0.031)$ & $(0.028)$ & $(0.032)$ & $(0.021)$ \\
\hline Impact of 1 p.p. Relative to Mean Institutionalization & $-2.9 \%$ & $-3.1 \%$ & $-2.3 \%$ & $-15.2 \%$ & $-2.5 \%$ & $-3.3 \%$ & $-2.9 \%$ & $-2.6 \%$ \\
\hline Number of Observations & $7,286,430$ & $6,573,745$ & 498,690 & 117,676 & $5,688,724$ & $1,597,705$ & $4,272,552$ & $3,013,878$ \\
\hline Number of Unique Observations & $4,294,262$ & $3,826,477$ & 345,620 & 72,092 & $3,256,971$ & $1,037,291$ & $2,540,670$ & $1,753,592$ \\
\hline Mean of Institutionalized & 0.0515 & 0.0524 & 0.0468 & 0.0370 & 0.0551 & 0.0404 & 0.0634 & 0.0341 \\
\hline F-statistic for weak instruments & 28.31 & 36.29 & 42.92 & 2.808 & 27.01 & 28.71 & 29.26 & 27.11 \\
\hline & & Non-Hispanic & Non-Hispanic & & & & & \\
\hline Dependent Variable: Institutionalized & All & White & Black & Hispanic & No College & Some College + & Female & Male \\
\hline Share Less-Educated Immigrant & $-0.380 * * *$ & $-0.409 * * *$ & $-0.438^{* * *}$ & 0.007 & $-0.387^{* * *}$ & $-0.258^{* *}$ & $-0.457^{* * *}$ & $-0.211 * *$ \\
\hline (Instrumented with Predicted Share) & $(0.074)$ & $(0.073)$ & $(0.162)$ & $(1.094)$ & $(0.085)$ & $(0.110)$ & $(0.089)$ & $(0.084)$ \\
\hline Impact of 1 p.p. Relative to Mean Institutionalization & $-2.6 \%$ & $-2.7 \%$ & $-3.8 \%$ & $-0.1 \%$ & $-2.6 \%$ & $-1.9 \%$ & $-2.7 \%$ & $-2.2 \%$ \\
\hline Number of Observations & $1,684,781$ & $1,536,209$ & 109,056 & 20,407 & $1,358,945$ & 325,828 & $1,118,311$ & 566,467 \\
\hline Number of Unique Observations & 972,848 & 878,218 & 72,819 & 11,834 & 766,379 & 206,469 & 653,459 & 319,389 \\
\hline Mean of Institutionalized & 0.148 & 0.152 & 0.114 & 0.120 & 0.151 & 0.135 & 0.172 & 0.0966 \\
\hline F-statistic for weak instruments & 33.44 & 39.96 & 44.23 & 3.224 & 33.32 & 31.81 & 35.01 & 30.95 \\
\hline
\end{tabular}

Robust standard errors in parentheses clustered on CZ.

Controls include $C Z$, year*age* race f.e., bpl*ace f.e., gender*marital status f.e., and education in 4 categories.

${ }^{* * *} \mathrm{p}<0.01,{ }^{* *} \mathrm{p}<0.05,{ }^{*} \mathrm{p}<0.1$. 
Table 4. Results Using Alternative Instrument, 1980-2000

Panel A. First Stage

Dependent Variable: Share Working-Age Population Less-Educated Immigrant

Age $80+$

Alternative Predicted Share Less-Educated

$0.489 * * *$

$0.480 * * *$

Immigrant Using Birth State

$(0.063)$

(0.064)

Panel B. Instrumental Variables Analysis

\begin{tabular}{lcc}
\hline Dependent Variable: Institutionalized & Age 65+ & Age 80+ \\
\hline Share Less-Educated Immigrant & $-0.161^{* * *}$ & $-0.522^{* * *}$ \\
(Instrumented with Alternative Predicted Share) & $(0.038)$ & $(0.114)$ \\
Number of Observations & & $1,684,781$ \\
Number of Unique Observations & $7,286,430$ & 972,848 \\
Mean of Institutionalized & $4,294,262$ & 0.148 \\
F-statistic for weak instruments & 0.0515 & 57.12 \\
\hline
\end{tabular}

Robust standard errors in parentheses clustered on CZ.

Controls include $\mathrm{CZ}$, year*age*race f.e., bpl*race f.e., gender*marital status f.e., and education in 4 categories. $* * * p<0.01, * * p<0.05, * p<0.1$. 
Table 5. Intrumental Variables Analysis Controlling for Lagged Cohort Institutionalization, 1980-2000

\begin{tabular}{|c|c|c|c|c|c|c|c|c|c|c|}
\hline Dependent Variable: Institutionalized & $\begin{array}{c}(1) \\
\text { All Ages }\end{array}$ & $\begin{array}{c}(2) \\
\text { All Ages }\end{array}$ & $\begin{array}{c}(3) \\
\text { All Ages }\end{array}$ & $\begin{array}{c}(4) \\
\text { All Ages }\end{array}$ & $\begin{array}{c}5) \\
\text { All Ages }\end{array}$ & $\begin{array}{c}6) \\
\text { Ages } 80+\end{array}$ & $\begin{array}{c}(7) \\
\text { Ages } 80+\end{array}$ & $\begin{array}{c}(8) \\
\text { Ages 80+ }\end{array}$ & $\begin{array}{c}(9) \\
\text { Ages } 80+\end{array}$ & $\begin{array}{c}(10) \\
\text { Ages } 80+\end{array}$ \\
\hline $\begin{array}{l}\text { Share Less-Educated Immigrant } \\
\text { (Instrumented with Alternative Predicted Share) }\end{array}$ & $\begin{array}{c}-0.151^{* * *} \\
(0.027)\end{array}$ & $\begin{array}{c}-0.146 * * * \\
(0.024)\end{array}$ & $\begin{array}{c}-0.148^{* * *} \\
(0.027)\end{array}$ & $\begin{array}{c}-0.152^{* * *} \\
(0.027)\end{array}$ & $\begin{array}{c}-0.152^{* * *} \\
(0.027)\end{array}$ & $\begin{array}{c}-0.380^{* * *} \\
(0.074)\end{array}$ & $\begin{array}{c}-0.356^{* * *} \\
(0.073)\end{array}$ & $\begin{array}{c}-0.357^{* * *} \\
(0.075)\end{array}$ & $\begin{array}{c}-0.376^{* * *} \\
(0.076)\end{array}$ & $\begin{array}{c}-0.381^{* * *} \\
(0.074)\end{array}$ \\
\hline Inst Rate of CZ-Birth Year Cohort, 10-yr Lag & & $\begin{array}{c}0.251^{* * *} \\
(0.034)\end{array}$ & & & & & $\begin{array}{c}0.165^{* * *} \\
(0.030)\end{array}$ & & & \\
\hline Inst Rate of Birth State-Birth Year Cohort, 10-yr Lag & & & $\begin{array}{c}0.522 * * * \\
(0.060)\end{array}$ & & & & & $\begin{array}{c}0.495 * * * \\
(0.070)\end{array}$ & & \\
\hline Inst Rate of Birth State-Birth Year Cohort, 20-yr Lag & & & & $\begin{array}{c}0.290^{* * *} \\
(0.089)\end{array}$ & & & & & $\begin{array}{l}0.262^{*} \\
(0.154)\end{array}$ & \\
\hline Inst Rate of Birth State-Birth Year Cohort, 30-yr Lag & & & & & $\begin{array}{r}0.118^{* *} \\
(0.051)\end{array}$ & & & & & $\begin{array}{c}0.203 \\
(0.130)\end{array}$ \\
\hline Number of Observations & $7,286,430$ & $7,185,865$ & $7,286,430$ & $7,286,430$ & $7,286,430$ & $1,684,781$ & $1,658,759$ & $1,684,781$ & $1,684,781$ & $1,684,781$ \\
\hline Number of Unique Observations & $4,294,262$ & $4,258,305$ & $4,294,262$ & $4,294,262$ & $4,294,262$ & 972,848 & 963,397 & 972,848 & 972,848 & 972,848 \\
\hline Mean of Institutionalized & 0.0515 & 0.0514 & 0.0515 & 0.0515 & 0.0515 & 0.148 & 0.148 & 0.148 & 0.148 & 0.148 \\
\hline F-statistic for weak instruments & 28.31 & 28.43 & 28.31 & 28.32 & 28.31 & 33.44 & 33.82 & 33.23 & 33.40 & 33.45 \\
\hline
\end{tabular}

Robust standard errors in parentheses clustered on CZ.

Controls include $C Z$, year*age*race f.e., bpl*race f.e., gender*marital status f.e., and education in 4 categories.

*** $p<0.01,{ }^{* *} p<0.05, * p<0.1$. 
Table 6. Incorporating Lagged Instruments

\begin{tabular}{|c|c|c|c|c|c|c|c|c|}
\hline Dependent Variable: Institutionalized & $\begin{array}{c}(1) \\
\text { All Ages } \\
1980-2000\end{array}$ & $\begin{array}{c}\text { (2) } \\
\text { All Ages } \\
1980-2000\end{array}$ & $\begin{array}{c}\text { (3) } \\
\text { All Ages } \\
1990-2000\end{array}$ & $\begin{array}{c}(4) \\
\text { All Ages } \\
1990-2000\end{array}$ & $\begin{array}{c}(5) \\
\text { Age 80+ } \\
1980-2000\end{array}$ & $\begin{array}{c}(6) \\
\text { Age } 80+ \\
1980-2000\end{array}$ & $\begin{array}{c}(7) \\
\text { Age 80+ } \\
1990-2000\end{array}$ & $\begin{array}{c}(8) \\
\text { Age 80+ } \\
1990-2000\end{array}$ \\
\hline Share Less-Educated Immigrant Lagged & & $\begin{array}{l}-0.099 \\
(0.304)\end{array}$ & & $\begin{array}{c}-1.545 \\
(14.514)\end{array}$ & & $\begin{array}{c}0.686 \\
(1.761)\end{array}$ & & $\begin{array}{l}-0.300 \\
(3.425)\end{array}$ \\
\hline F-statistic for weak instruments & 28.31 & 0.390 & 31.97 & 0.00583 & 33.44 & 0.418 & 37.96 & 0.0364 \\
\hline LM Statistic for Under ID test & 5.230 & 0.673 & 6.666 & 0.0113 & 5.116 & 0.693 & 6.656 & 0.0668 \\
\hline P-value for Under ID test & 0.0222 & 0.412 & 0.00983 & 0.915 & 0.0237 & 0.405 & 0.00988 & 0.796 \\
\hline
\end{tabular}

Robust standard errors in parentheses clustered on CZ.

Controls include CZ, year*age*race f.e., bpl*race f.e., gender*marital status f.e., and education in 4 categories. In columns (1), (3), (5), and (7), share less educated immigrant is instrumented with predicted share less-educated immigrant. In columns (2), (4), (6), and (8), share less-educated immigrant and its lag are instrumented by predicted share less-educated immigrant and its lag.

$* * * p<0.01, * * p<0.05, * p<0.1$. 
Table 7. Robustness, Age $65+$ Sample 1980-2000

\begin{tabular}{|c|c|c|c|c|c|c|c|c|c|c|c|c|}
\hline Dependent Variable: Institutionalized & Baseline & $\begin{array}{c}\text { (2) } \\
\text { Control for } \\
\text { Linear Trends } \\
\text { in Initial } \\
\text { Immigrant } \\
\text { Share }\end{array}$ & $\begin{array}{c}(3) \\
\text { Control for } \\
\text { Year*Initial } \\
\text { Immigrant } \\
\text { Share }\end{array}$ & $\begin{array}{c}\text { (4) } \\
\text { Control for } \\
\text { Region- } \\
\text { Specific Linear } \\
\text { Trends }\end{array}$ & $\begin{array}{l}\text { Control for } \\
\text { Year*Region }\end{array}$ & $\begin{array}{c}\text { Control for } \\
\text { State-Specific } \\
\text { Linear Trends }\end{array}$ & $\begin{array}{l}\text { Control for } \\
\text { Year*State }\end{array}$ & $\begin{array}{l}\text { Control for } \\
\text { Median Rent }\end{array}$ & $\begin{array}{c}\text { (9) } \\
\text { Control for } \\
\text { Median } \\
\text { Property } \\
\text { Taxes and } \\
\text { Insurance }\end{array}$ & $\begin{array}{c}\text { Drop } \\
\text { California }\end{array}$ & $\begin{array}{c}\text { Drop All } \\
\text { Demographic } \\
\text { Controls }\end{array}$ & $\begin{array}{c}\text { (12) } \\
\text { Drop All } \\
\text { Demographic } \\
\text { Controls } \\
\text { Except Age }\end{array}$ \\
\hline Share Less-Educated Immigrant & $\begin{array}{c}-0.151^{* * *} \\
(0.027)\end{array}$ & $\begin{array}{c}-0.162^{* *} \\
(0.082)\end{array}$ & $\begin{array}{c}-0.182^{* *} \\
(0.080)\end{array}$ & $\begin{array}{c}-0.150^{* * * *} \\
(0.026)\end{array}$ & $\begin{array}{c}-0.076^{* *} \\
(0.036)\end{array}$ & $\begin{array}{c}-0.152^{* * * *} \\
(0.027)\end{array}$ & $\begin{array}{c}-0.061 \\
(0.058)\end{array}$ & $\begin{array}{c}-0.151^{* * * *} \\
(0.028)\end{array}$ & $\begin{array}{c}-0.166 * * * \\
(0.029)\end{array}$ & $\begin{array}{c}-0.090^{* *} \\
(0.045)\end{array}$ & $\begin{array}{l}-0.081^{*} \\
(0.048)\end{array}$ & $\begin{array}{c}-0.111^{* * *} \\
(0.032)\end{array}$ \\
\hline Linear Trends * Initial Immigrant Share (continuous) & & $\mathrm{x}$ & & & & & & & & & & \\
\hline Year* Initial Immigrant Share & & & $\mathrm{x}$ & & & & & & & & & \\
\hline Linear Trends * Region & & & & $\mathrm{x}$ & & & & & & & & \\
\hline Year* Region & & & & & $\mathrm{x}$ & & & & & & & \\
\hline Linear Trends * State & & & & & & $\mathrm{x}$ & & & & & & \\
\hline Year *State & & & & & & & $\mathrm{x}$ & & & & & \\
\hline Median Rent & & & & & & & & $\mathrm{x}$ & & & & \\
\hline Median Property Taxes and Insurance & & & & & & & & & $\mathrm{x}$ & & & \\
\hline Drop CA & & & & & & & & & & $\mathrm{x}$ & & \\
\hline Drop Demographic Controls & & & & & & & & & & & $\mathrm{x}$ & \\
\hline Drop Demographic Controls Except Age & & & & & & & & & & & & $\mathrm{x}$ \\
\hline Number of Observations & $7,286,430$ & $7,286,430$ & $7,286,430$ & $7,286,430$ & $7,286,430$ & $7,286,430$ & $7,286,430$ & $7,286,430$ & $7,197,972$ & $6,891,661$ & $7,286,430$ & $7,286,430$ \\
\hline Number of Unique Observations & $4,294,262$ & $4,294,262$ & $4,294,262$ & $4,294,262$ & $4,294,262$ & $4,294,262$ & $4,294,262$ & $4,294,262$ & $4,262,968$ & $3,926,260$ & $4,294,262$ & $4,294,262$ \\
\hline Mean of Instititutionalized & 0.0515 & 0.0515 & 0.0515 & 0.0515 & 0.0514 & 0.0515 & 0.0514 & 0.0515 & 0.0514 & 0.0521 & 0.0515 & 0.0515 \\
\hline F-statistic for weak instruments & 28.31 & 10.15 & 8.202 & 28.37 & 18.36 & 28.01 & 4.847 & 24.26 & 20.51 & 9.217 & 27.91 & 27.90 \\
\hline
\end{tabular}

Robust standard errors in parentheses clustered on CZ.

Controls include CZ, year*age*race f.e., bpl*race f.e., gender*marital status f.e., and education in 4 categories. Column (11) includes CZ f.e. and year f.e. Column (12) includes $\mathrm{CZ}$ f.e., year f.e., and age f.e.

${ }^{* * *} \mathrm{p}<0.01,{ }^{* *} \mathrm{p}<0.05,{ }^{*} \mathrm{p}<0.1$ 
Table 8. Labor Market Impacts, 1980-2000

\begin{tabular}{|c|c|c|c|c|c|c|}
\hline & (1) & (2) & (3) & (4) & (5) & (6) \\
\hline & \multicolumn{3}{|c|}{ Median FTFY } & & \multirow[b]{2}{*}{$\begin{array}{c}\text { Log(Annual } \\
\text { Hours) }\end{array}$} & \multirow[b]{2}{*}{$\begin{array}{l}\text { Share of Total } \\
\text { Hours Worked }\end{array}$} \\
\hline & $\begin{array}{c}\text { Log (Median FTFY } \\
\text { Hourly Wage in } \\
\text { Occ) }\end{array}$ & $\begin{array}{l}\text { Hourly Wage in } \\
\text { Occ/CZ Median } \\
\text { FTFY Hourly Wage }\end{array}$ & Log(Employment) & $\begin{array}{c}\text { Employment/ } \\
\text { Working Age } \\
\text { Population } \\
\end{array}$ & & \\
\hline \multirow[t]{2}{*}{ Nursing and non-nursing health aides } & $-2.4740 * * *$ & $-1.1812 * * *$ & $2.1675^{* *}$ & $0.0437^{*}$ & $1.7752 * *$ & $0.0414^{*}$ \\
\hline & $(0.329)$ & $(0.348)$ & $(0.973)$ & $(0.025)$ & $(0.904)$ & $(0.024)$ \\
\hline \multirow[t]{2}{*}{ Home Health Aides } & $-3.2055^{* * *}$ & -0.6298 & $3.9066 * * *$ & $0.0548^{* *}$ & $3.5310^{*}$ & $0.0516^{*}$ \\
\hline & $(0.518)$ & $(0.509)$ & $(1.419)$ & $(0.024)$ & $(1.828)$ & $(0.027)$ \\
\hline \multirow[t]{2}{*}{ Nursing Home Health Aides } & $-2.2418 * * *$ & $-1.2995^{* * *}$ & $3.0369 * *$ & 0.0034 & $3.5207^{* *}$ & -0.0022 \\
\hline & $(0.281)$ & -0.173 & $(1.376)$ & $(0.003)$ & $(1.456)$ & $(0.003)$ \\
\hline \multirow[t]{2}{*}{ Other Health Aides } & $-0.7055^{* * *}$ & $-0.5904 * * *$ & $-2.1713^{* *}$ & $-0.0145 * * *$ & $-1.4624^{*}$ & -0.0079 \\
\hline & $(0.227)$ & $(0.171)$ & $(0.903)$ & $(0.004)$ & $(0.793)$ & $(0.005)$ \\
\hline \multirow[t]{2}{*}{ Licensed Practical Nurses } & $-0.7802 * *$ & -0.2150 & -1.4593 & $-0.0086 * * *$ & -1.0365 & $-0.0072 * *$ \\
\hline & $(0.396)$ & $(0.386)$ & $(1.030)$ & $(0.003)$ & $(0.977)$ & $(0.004)$ \\
\hline \multirow[t]{2}{*}{ Registered Nurses } & 0.2607 & $1.2019 * *$ & $-3.0826 * * *$ & $-0.0439 * * *$ & $-3.0044 * * *$ & $-0.0429 * * *$ \\
\hline & $(0.552)$ & $(0.557)$ & $(1.000)$ & $(0.005)$ & $(0.940)$ & (0.009) \\
\hline \multirow[t]{2}{*}{ Housekeepers and Gardeners } & $-2.0309 * * *$ & $-1.4991 * * *$ & -0.3011 & $0.0201 * * *$ & 0.3715 & 0.0074 \\
\hline & $(0.274)$ & $(0.368)$ & $(1.115)$ & $(0.007)$ & $(1.413)$ & $(0.007)$ \\
\hline \multirow[t]{2}{*}{ Construction Workers } & $-1.7887^{* * *}$ & $-1.7210 * * *$ & $-2.5875^{* * *}$ & $-0.0466 * * *$ & -0.7819 & -0.0152 \\
\hline & $(0.329)$ & $(0.492)$ & $(0.628)$ & $(0.013)$ & $(0.701)$ & $(0.015)$ \\
\hline \multirow[t]{2}{*}{ All other (no college) } & $-1.0794^{* * *}$ & -0.1464 & -0.2813 & $0.7088 * * *$ & 0.4950 & $0.6165^{* * *}$ \\
\hline & $(0.207)$ & $(0.122)$ & $(0.805)$ & $(0.146)$ & $(0.785)$ & $(0.172)$ \\
\hline \multirow[t]{2}{*}{ All other } & -0.2500 & 0.0442 & $-0.9221^{*}$ & 0.0352 & -0.4492 & 0.0163 \\
\hline & $(0.336)$ & $(0.047)$ & (0.499) & $(0.032)$ & $(0.481)$ & $(0.033)$ \\
\hline
\end{tabular}

Notes: Each cell represents key coefficient on share less-educated immigrant from a different 2SLS regression at the CZ-year level.

Regressions weighted by CZ working age population. Controls include CZ and year fixed effects.Standard errors clustered at the CZ level.

$* * * p<0.01, * * p<0.05, * p<0.1$. 
Share Who Receive ADL

Help from:
Share Who Receive IADL Help from:

\begin{tabular}{lll} 
Spouse & 0.496 & 0.420 \\
Daughter & 0.253 & 0.322 \\
Son & 0.104 \\
Daughter-In-Law & 0.036 \\
Other Relative & 0.161 & 0.052 \\
Other & 0.185 \\
Number of Observations & 0.197 \\
\hline
\end{tabular}

Notes: Data are from Health and Retirement Survey 2002 and 2004. Sample is native born 55-to-90-year-olds who report receiving help with Activities of Daily Living or help with Instrumental Activities of Daily Living. People may receive help from multiple sources. 


\begin{tabular}{lcccc}
\hline & $\begin{array}{c}(1) \\
1980-2000 \\
\text { Age 65+ }\end{array}$ & $\begin{array}{c}(2) \\
1980-2000 \\
\text { Age 80+ }\end{array}$ & $\begin{array}{c}(3) \\
1980-2017 \\
\text { Age 65+ }\end{array}$ & $\begin{array}{c}\text { (4) } \\
\text { Age 80+ }\end{array}$ \\
\hline & & & & \\
Institutionalized & 0.051 & 0.148 & 0.041 & 0.111 \\
Age & 74.210 & 84.599 & 74.452 & 85.064 \\
Female & 0.594 & 0.678 & 0.577 & 0.650 \\
Married & 0.539 & 0.329 & 0.545 & 0.350 \\
Non-Hispanic White & 0.887 & 0.900 & 0.873 & 0.887 \\
Non-Hispanic Black & 0.085 & 0.078 & 0.089 & 0.078 \\
Hispanic & 0.017 & 0.012 & 0.024 & 0.021 \\
HS Grad Exactly & 0.339 & 0.297 & 0.382 & 0.383 \\
Some College & 0.127 & 0.112 & 0.156 & 0.129 \\
College Grad or More & 0.120 & 0.105 & 0.184 & 0.151 \\
Share Less-Educated Immigrant in CZ & 0.054 & 0.055 & 0.064 & 0.066 \\
Predicted Share Less-Educated Immigrant in CZ & 0.054 & 0.055 & 0.061 & 0.064 \\
Predicted Share Less-Educated Immigrant in CZ (Alternative) & 0.056 & 0.058 & 0.069 & 0.070 \\
Wage of Less-Educated Workers Relative to Median in CZ & 0.866 & 0.865 & 0.829 & 0.826 \\
Share of Hours Worked by Less Educated in CZ & 0.520 & 0.514 & 0.464 & 0.457 \\
& & & & \\
\hline
\end{tabular}

Note: Weighted means for each sample of U.S. born elderly individuals. 
Appendix Table 3. Subgroup Analysis, 1980-2017

Panel A. Instrumental Variables Analysis - Ages 65+ (1980-2017)

\begin{tabular}{|c|c|c|c|c|c|c|c|c|}
\hline Denendent Variable Institutionalized & All & Non-Hispanic & $\begin{array}{l}\text { Non-Hispanic } \\
\text { Black }\end{array}$ & Hisnanic & $\mathrm{No}$ College & Some College + & Female & Male \\
\hline $\begin{array}{l}\text { Share Less-Educated Immigrant } \\
\text { (Instrumented with Predicted Share) }\end{array}$ & $\begin{array}{c}-0.310^{* * *} \\
(0.113)\end{array}$ & $\begin{array}{c}-0.307^{* * *} \\
(0.102)\end{array}$ & $\begin{array}{l}-0.240 \\
(0.218)\end{array}$ & $\begin{array}{c}0.850 \\
(1.431)\end{array}$ & $\begin{array}{c}-0.267^{* *} \\
(0.105)\end{array}$ & $\begin{array}{l}-0.203 \\
(0.191)\end{array}$ & $\begin{array}{c}-0.410^{* * *} \\
(0.133)\end{array}$ & $\begin{array}{l}-0.137^{*} \\
(0.083)\end{array}$ \\
\hline Impact of 1 p.p. Relative to Mean Institutionalization & $-7.5 \%$ & $-7.4 \%$ & $-5.3 \%$ & $29.7 \%$ & $-5.5 \%$ & $-7.5 \%$ & $-8.1 \%$ & $-4.8 \%$ \\
\hline Number of Observations & $9,549,816$ & $8,563,499$ & 661,045 & 180,264 & $7,002,781$ & $2,547,032$ & $5,516,018$ & $4,033,796$ \\
\hline Number of Unique Observations & $5,263,701$ & $4,671,077$ & 423,606 & 99,442 & $3,806,774$ & $1,456,927$ & $3,078,705$ & $2,184,996$ \\
\hline Mean of Institutionalized & 0.0414 & 0.0416 & 0.0450 & 0.0286 & 0.0488 & 0.0270 & 0.0508 & 0.0285 \\
\hline F-statistic for weak instruments & 35.01 & 43.41 & 18.68 & 0.550 & 37.97 & 11.29 & 37.52 & 31.55 \\
\hline Denendent Variable· Institutionalized & All & $\begin{array}{l}\text { Non-Hispanic } \\
\text { White }\end{array}$ & $\begin{array}{l}\text { Non-Hispanic } \\
\text { Black }\end{array}$ & Hisnanic & No College & Some College + & Female & Male \\
\hline $\begin{array}{l}\text { Share Less-Educated Immigrant } \\
\text { (Instrumented with Predicted Share) }\end{array}$ & $\begin{array}{c}-0.815^{* * *} \\
(0.243)\end{array}$ & $\begin{array}{c}-0.774^{* * *} \\
(0.216)\end{array}$ & $\begin{aligned}-1.237^{*} \\
(0.699)\end{aligned}$ & $\begin{array}{c}18.860 \\
(401.403)\end{array}$ & $\begin{array}{c}-0.818^{* * *} \\
(0.241)\end{array}$ & $\begin{array}{l}-0.285 \\
(0.441)\end{array}$ & $\begin{array}{c}-1.031^{* * *} \\
(0.290)\end{array}$ & $\begin{array}{l}-0.307 \\
(0.221)\end{array}$ \\
\hline Impact of 1 p.p. Relative to Mean Institutionalization & $-7.3 \%$ & $-6.8 \%$ & $-12.1 \%$ & $267.1 \%$ & $-6.8 \%$ & $-3.3 \%$ & $-7.9 \%$ & $-4.3 \%$ \\
\hline Number of Observations & $2,259,070$ & $2,047,102$ & 146,283 & 35,883 & $1,750,889$ & 508,170 & $1,469,539$ & 789,529 \\
\hline Number of Unique Observations & $1,224,951$ & $1,100,820$ & 90,936 & 18,562 & 934,364 & 290,587 & 809,124 & 415,827 \\
\hline Mean of Institutionalized & 0.111 & 0.113 & 0.102 & 0.0706 & 0.120 & 0.0867 & 0.131 & 0.0718 \\
\hline F-statistic for weak instruments & 45.06 & 52.79 & 17.76 & 0.00223 & 48.43 & 16.17 & 47.64 & 39.17 \\
\hline
\end{tabular}

Robust standard errors in parentheses clustered on CZ.

Controls include $\mathrm{CZ}$, year*age* race f.e., bpl*race f.e., gender*marital status f.e., and education in 4 categories.

${ }^{* * *} p<0.01,{ }^{* *} p<0.05,{ }^{*} p<0.1$. 
Appendix Table 4. Results Using Alternative Instrument, 1980-2017

Panel A. First Stage

Dependent Variable: Share Working-Age Population Less-Educated Immigrant

Alternative Predicted Share Less-Educated

$0.256 * * *$

$0.254 * * *$

Immigrant Using Birth State

(0.047)

(0.047)

Panel B. Instrumental Variables Analysis

\begin{tabular}{lcc}
\hline Dependent Variable: Institutionalized & Age 65+ & Age 80+ \\
\hline Share Less-Educated Immigrant & $-0.297^{* * *}$ & $-0.816^{* * *}$ \\
(Instrumented with Alternative Predicted Share) & $(0.075)$ & $(0.198)$ \\
Number of Observations & & $2,259,070$ \\
Number of Unique Observations & $9,549,816$ & $1,224,951$ \\
Mean of Institutionalized & $5,263,701$ & 0.111 \\
F-statistic for weak instruments & 0.0414 & 29.91 \\
\hline
\end{tabular}

Robust standard errors in parentheses clustered on CZ.

Controls include $\mathrm{CZ}$, year*age*race f.e., bpl*race f.e., gender*marital status f.e., and education in 4 categories. $* * * p<0.01, * * p<0.05, * p<0.1$. 
Appendix Table 5. Intrumental Variables Analysis Controlling for Lagged Cohort Institutionalization, 1980-2017

\begin{tabular}{|c|c|c|c|c|c|c|c|c|c|c|}
\hline Dependent Variable: Institutionalized & $\begin{array}{c}(1) \\
\text { All Ages }\end{array}$ & $\begin{array}{c}(2) \\
\text { All Ages }\end{array}$ & $\begin{array}{c}(3) \\
\text { All Ages } \\
\end{array}$ & $\begin{array}{c}(4) \\
\text { All Ages } \\
\end{array}$ & $\begin{array}{c}\text { (5) } \\
\text { All Ages }\end{array}$ & $\begin{array}{c}6) \\
\text { Ages } 80+ \\
\end{array}$ & $\begin{array}{c}(7) \\
\text { Ages } 80+ \\
\end{array}$ & $\begin{array}{c}(8) \\
\text { Ages } 80+\end{array}$ & $\begin{array}{c}9) \\
\text { Ages } 80+ \\
\end{array}$ & $\begin{array}{c}(10) \\
\text { Ages } 80+ \\
\end{array}$ \\
\hline $\begin{array}{l}\text { Share Less-Educated Immigrant } \\
\text { (Instrumented with Alternative Predicted Share) }\end{array}$ & $\begin{array}{c}-0.310^{* * *} \\
(0.113)\end{array}$ & $\begin{array}{c}-0.305^{* * *} \\
(0.105)\end{array}$ & $\begin{array}{c}-0.298^{* * *} \\
(0.113)\end{array}$ & $\begin{array}{c}-0.317^{* * *} \\
(0.115)\end{array}$ & $\begin{array}{c}-0.315^{* * *} \\
(0.114)\end{array}$ & $\begin{array}{c}-0.815^{* * *} \\
(0.243)\end{array}$ & $\begin{array}{c}-0.787^{* * *} \\
(0.222)\end{array}$ & $\begin{array}{c}-0.766^{* * *} \\
(0.240)\end{array}$ & $\begin{array}{c}-0.795^{* * *} \\
(0.250)\end{array}$ & $\begin{array}{c}-0.821^{* * *} \\
(0.241)\end{array}$ \\
\hline Inst Rate of CZ-Birth Year Cohort, 10-yr Lag & & $\begin{array}{c}0.381^{* * *} \\
(0.041)\end{array}$ & & & & & $\begin{array}{c}0.264^{* * *} \\
(0.036)\end{array}$ & & & \\
\hline Inst Rate of Birth State-Birth Year Cohort, 10-yr Lag & & & $\begin{array}{c}0.565^{* * *} \\
(0.054)\end{array}$ & & & & & $\begin{array}{c}0.450^{* * *} \\
(0.061)\end{array}$ & & \\
\hline Inst Rate of Birth State-Birth Year Cohort, 20-yr Lag & & & & $\begin{array}{c}0.496^{* * *} \\
(0.084)\end{array}$ & & & & & $\begin{array}{c}0.723^{* * *} \\
(0.158)\end{array}$ & \\
\hline Inst Rate of Birth State-Birth Year Cohort, 30-yr Lag & & & & & $\begin{array}{c}0.189 * * * \\
(0.057)\end{array}$ & & & & & $\begin{array}{l}0.259^{*} \\
(0.138)\end{array}$ \\
\hline Number of Observations & $9,549,816$ & $9,449,251$ & $9,549,816$ & $9,549,816$ & $9,549,816$ & $2,259,070$ & $2,233,048$ & $2,259,070$ & $2,259,070$ & $2,259,070$ \\
\hline Number of Unique Observations & $5,263,701$ & $5,227,744$ & $5,263,701$ & $5,263,701$ & $5,263,701$ & $1,224,951$ & $1,215,500$ & $1,224,951$ & $1,224,951$ & $1,224,951$ \\
\hline Mean of Institutionalized & 0.0414 & 0.0413 & 0.0414 & 0.0414 & 0.0414 & 0.111 & 0.110 & 0.111 & 0.111 & 0.111 \\
\hline F-statistic for weak instruments & 35.01 & 34.87 & 34.97 & 34.75 & 34.96 & 45.06 & 44.80 & 44.85 & 44.67 & 45.09 \\
\hline
\end{tabular}

Robust standard errors in parentheses clustered on $\mathrm{CZ}$.

Controls include CZ, year*age*race f.e., bpl*race f.e., gender*marital status f.e., and education in 4 categories.

*** $p<0.01,{ }^{* *} p<0.05, * p<0.1$. 
Appendix Table 6. Incorporating Lagged Instruments, 1980-2017

\begin{tabular}{|c|c|c|c|c|c|c|c|c|}
\hline Dependent Variable: Institutionalized & $\begin{array}{c}\text { (1) } \\
\text { All Ages } \\
1980-2017\end{array}$ & $\begin{array}{c}\text { (2) } \\
\text { All Ages } \\
1980-2017\end{array}$ & $\begin{array}{c}(3) \\
\text { All Ages } \\
1990-2017\end{array}$ & $\begin{array}{c}(4) \\
\text { All Ages } \\
1990-2017\end{array}$ & $\begin{array}{c}(5) \\
\text { Age 80+ } \\
1980-2017\end{array}$ & $\begin{array}{c}(6) \\
\text { Age } 80+ \\
1980-2017\end{array}$ & $\begin{array}{c}(7) \\
\text { Age 80+ } \\
1990-2017\end{array}$ & $\begin{array}{c}(8) \\
\text { Age } 80+ \\
1990-2017\end{array}$ \\
\hline Share Less-Educated Immigrant & $\begin{array}{c}-0.310 * * * \\
(0.113)\end{array}$ & $\begin{array}{l}-0.076 \\
(0.061)\end{array}$ & $\begin{array}{l}-2.104 \\
(6.732)\end{array}$ & $\begin{array}{l}-0.074 \\
(0.064)\end{array}$ & $\begin{array}{c}-0.815 * * * \\
(0.243)\end{array}$ & $\begin{array}{l}-0.115 \\
(0.111)\end{array}$ & $\begin{array}{l}-3.642 \\
(8.163)\end{array}$ & $\begin{array}{l}-0.117 \\
(0.109)\end{array}$ \\
\hline Share Less-Educated Immigrant Lagged & & $\begin{array}{c}-0.083 * * \\
(0.040)\end{array}$ & & $\begin{array}{c}-0.098 * * \\
(0.045)\end{array}$ & & $\begin{array}{c}-0.243 * * * \\
(0.072)\end{array}$ & & $\begin{array}{c}-0.226 * * \\
(0.089)\end{array}$ \\
\hline Number of Observations & $9,549,816$ & $9,549,816$ & $7,628,068$ & $7,628,068$ & $2,259,070$ & $2,259,070$ & $1,885,451$ & $1,885,451$ \\
\hline Number of Unique Observations & $5,263,701$ & $5,263,701$ & $4,142,325$ & $4,142,325$ & $1,224,951$ & $1,224,951$ & $1,013,694$ & $1,013,694$ \\
\hline F-statistic for weak instruments & 35.01 & 12.88 & 0.126 & 10.75 & 45.06 & 13.20 & 0.263 & 11.26 \\
\hline LM Statistic for Under ID test & 8.744 & 4.892 & 0.145 & 4.330 & 9.125 & 4.583 & 0.327 & 4.287 \\
\hline P-value for Under ID test & 0.00311 & 0.0270 & 0.703 & 0.0375 & 0.00252 & 0.0323 & 0.568 & 0.0384 \\
\hline
\end{tabular}

Robust standard errors in parentheses clustered on CZ.

Controls include CZ, year*age*race f.e., bpl*race f.e., gender*marital status f.e., and education in 4 categories. In columns (1), (3), (5), and (7), share less educated immigrant is instrumented with predicted share less-educated immigrant. In columns (2), (4), (6), and (8), share less-educated immigrant and its lag are instrumented by predicted share less-educated immigrant and its lag.

*** $\mathrm{p}<0.01, * * \mathrm{p}<0.05, * \mathrm{p}<0.1$. 
Appendix Table 7. Robustness Across Samples

\begin{tabular}{|c|c|c|c|c|c|c|c|c|c|c|c|c|}
\hline Sample & Baseline & $\begin{array}{c}(2) \\
\text { Control for } \\
\text { Linear Trends } \\
\text { in Initial } \\
\text { Immigrant } \\
\text { Share } \\
\end{array}$ & $\begin{array}{c}\text { (3) } \\
\text { Control for } \\
\text { Year*Initial } \\
\text { Immigrant } \\
\text { Share } \\
\end{array}$ & $\begin{array}{c}(4) \\
\text { Control for } \\
\text { Region- } \\
\text { Specific Linear } \\
\text { Trends } \\
\end{array}$ & $\begin{array}{l}\text { Control for } \\
\text { Year*Region }\end{array}$ & $\begin{array}{c}\text { (6) } \\
\\
\text { Control for } \\
\text { State-Specific } \\
\text { Linear Trends } \\
\end{array}$ & $\begin{array}{l}\text { Control for } \\
\text { Year*State }\end{array}$ & $\begin{array}{l}\text { Control for } \\
\text { Median Rent } \\
\end{array}$ & $\begin{array}{c}\text { (9) } \\
\text { Control for } \\
\text { Median } \\
\text { Property } \\
\text { Taxes and } \\
\text { Insurance } \\
\end{array}$ & $\begin{array}{c}\text { Drop } \\
\text { California } \\
\end{array}$ & $\begin{array}{c}\text { Drop All } \\
\text { Demographic } \\
\text { Controls }\end{array}$ & $\begin{array}{c}\text { (12) } \\
\text { Drop All } \\
\text { Demographic } \\
\text { Controls } \\
\text { Except Age } \\
\end{array}$ \\
\hline Age $65+, 1980-2000$ (Primary Sample) & $\begin{array}{c}-0.151^{* * * *} \\
(0.027)\end{array}$ & $\begin{array}{c}-0.162^{* *} \\
(0.082)\end{array}$ & $\begin{array}{c}-0.182^{* *} \\
(0.080)\end{array}$ & $\begin{array}{c}-0.150^{* * * *} \\
(0.026)\end{array}$ & $\begin{array}{c}-0.076^{* *} \\
(0.036)\end{array}$ & $\begin{array}{c}-0.152^{* * * *} \\
(0.027)\end{array}$ & $\begin{array}{c}-0.061 \\
(0.058)\end{array}$ & $\begin{array}{c}-0.151^{* * * *} \\
(0.028)\end{array}$ & $\begin{array}{c}-0.166 * * * \\
(0.029)\end{array}$ & $\begin{array}{c}-0.090^{* *} \\
(0.045)\end{array}$ & $\begin{array}{l}-0.081^{*} \\
(0.048)\end{array}$ & $\begin{array}{c}-0.111^{* * *} \\
(0.032)\end{array}$ \\
\hline Age $80+, 1980-2000$ & $\begin{array}{c}-0.380 * * * \\
(0.074)\end{array}$ & $\begin{array}{l}-0.498^{*} \\
(0.269)\end{array}$ & $\begin{array}{c}-0.557^{* *} \\
(0.259)\end{array}$ & $\begin{array}{c}-0.377^{* * *} \\
(0.074)\end{array}$ & $\begin{array}{c}-0.194^{* *} \\
(0.096)\end{array}$ & $\begin{array}{c}-0.388 * * * \\
(0.073)\end{array}$ & $\begin{array}{c}0.062 \\
(0.147)\end{array}$ & $\begin{array}{c}-0.378^{* * *} \\
(0.078)\end{array}$ & $\begin{array}{c}-0.425 * * * \\
(0.082)\end{array}$ & $\begin{array}{l}-0.189^{*} \\
(0.114)\end{array}$ & $\begin{array}{c}-0.358^{* * * *} \\
(0.104)\end{array}$ & $\begin{array}{c}-0.347^{* * *} \\
(0.088)\end{array}$ \\
\hline Age $65+, 1980-2017$ & $\begin{array}{c}-0.310^{* * *} \\
(0.113)\end{array}$ & $\begin{array}{c}-0.264^{* *} \\
(0.125)\end{array}$ & $\begin{array}{l}-0.464 \\
(0.313)\end{array}$ & $\begin{array}{c}-0.308^{* * * *} \\
(0.112)\end{array}$ & $\begin{array}{c}-0.219 \\
(0.137)\end{array}$ & $\begin{array}{c}-0.328^{* * * *} \\
(0.114)\end{array}$ & $\begin{array}{c}-0.108 \\
(0.237)\end{array}$ & $\begin{array}{c}-0.292^{* *} \\
(0.119)\end{array}$ & $\begin{array}{c}-0.380^{* *} \\
(0.150)\end{array}$ & $\begin{array}{c}-0.086 \\
(0.056)\end{array}$ & $\begin{array}{l}-0.071 \\
(0.146)\end{array}$ & $\begin{array}{l}-0.195 \\
(0.122)\end{array}$ \\
\hline Age $80+, 1980-2017$ & $\begin{array}{c}-0.815 * * * \\
(0.243)\end{array}$ & $\begin{array}{c}-0.676^{* *} \\
(0.294)\end{array}$ & $\begin{array}{l}-1.322^{*} \\
(0.763)\end{array}$ & $\begin{array}{c}-0.810^{* * * *} \\
(0.240)\end{array}$ & $\begin{array}{l}-0.685^{*} \\
(0.404)\end{array}$ & $\begin{array}{c}-0.863^{* * *} \\
(0.243)\end{array}$ & $\begin{array}{l}-0.061 \\
(0.494)\end{array}$ & $\begin{array}{c}-0.754^{* * *} \\
(0.238)\end{array}$ & $\begin{array}{c}-0.944 * * * \\
(0.305)\end{array}$ & $\begin{array}{l}-0.360 \\
(0.220)\end{array}$ & $\begin{array}{l}-0.611^{*} \\
(0.335)\end{array}$ & $\begin{array}{c}-0.725 * * \\
(0.302)\end{array}$ \\
\hline
\end{tabular}

Each cell represents the key coefficient from a different 2SLS regression. See Table 7 for notes. 


\begin{tabular}{|c|c|c|c|c|c|c|}
\hline & (1) & $(2)$ & (3) & (4) & $(5)$ & (6) \\
\hline & $\begin{array}{c}\text { Log (Median FTFY } \\
\text { Hourly Wage in } \\
\text { Occ) }\end{array}$ & $\begin{array}{c}\text { Median FTFY } \\
\text { Hourly Wage in } \\
\text { Occ/CZ Median } \\
\text { FTFY Hourly Wage }\end{array}$ & Log(Employment) & $\begin{array}{c}\text { Employment/ } \\
\text { Working Age } \\
\text { Population } \\
\end{array}$ & $\begin{array}{c}\text { Log(Annual } \\
\text { Hours) }\end{array}$ & $\begin{array}{l}\text { Share of Total } \\
\text { Hours Worked }\end{array}$ \\
\hline Nursing and non-nursing health aides & $\begin{array}{c}-7.4460 * * * \\
(1.692)\end{array}$ & $\begin{array}{c}-2.8345^{* * *} \\
(1.067)\end{array}$ & $\begin{array}{c}9.8012^{* * *} \\
(3.310)\end{array}$ & $\begin{array}{c}0.1837^{* * *} \\
(0.060)\end{array}$ & $\begin{array}{c}8.3117^{* * *} \\
(2.871)\end{array}$ & $\begin{array}{c}0.1994 * * * \\
(0.067)\end{array}$ \\
\hline Home Health Aides & $\begin{array}{c}-5.7451^{* * *} \\
(1.412)\end{array}$ & $\begin{array}{r}-1.2902 \\
(1.107)\end{array}$ & $\begin{array}{c}11.2067^{* * *} \\
(4.016)\end{array}$ & $\begin{array}{c}0.2273^{* * *} \\
(0.081)\end{array}$ & $\begin{array}{c}10.1837^{* *} \\
(4.028)\end{array}$ & $\begin{array}{c}0.2602 * * * \\
(0.100)\end{array}$ \\
\hline Nursing Home Health Aides & $\begin{array}{c}-4.3634 * * * \\
(1.113)\end{array}$ & $\begin{array}{l}-0.9973 \\
(1.064)\end{array}$ & $\begin{array}{c}10.0004 \\
(7.069)\end{array}$ & $\begin{array}{l}-0.0022 \\
(0.011)\end{array}$ & $\begin{array}{c}11.4159 \\
(7.712)\end{array}$ & $\begin{array}{c}-0.0244^{*} \\
(0.014)\end{array}$ \\
\hline Other Health Aides & $\begin{array}{c}-2.4707^{* * *} \\
(0.951)\end{array}$ & $\begin{array}{l}-0.5869 \\
(0.660)\end{array}$ & $\begin{array}{l}-4.8157 \\
(4.534)\end{array}$ & $\begin{array}{c}-0.0403^{*} \\
(0.022)\end{array}$ & $\begin{array}{l}-4.4571 \\
(4.154)\end{array}$ & $\begin{array}{l}-0.0349 \\
(0.034)\end{array}$ \\
\hline Licensed Practical Nurses & $\begin{array}{c}-2.0531^{* *} \\
(1.002)\end{array}$ & $\begin{array}{l}0.9078 \\
(1.112)\end{array}$ & $\begin{array}{l}2.1308 \\
(3.030)\end{array}$ & $\begin{array}{l}-0.0097 \\
(0.007)\end{array}$ & $\begin{array}{l}2.8403 \\
(3.050)\end{array}$ & $\begin{array}{r}-0.0072 \\
(0.011)\end{array}$ \\
\hline Registered Nurses & $\begin{array}{c}2.2594^{*} \\
(1.194)\end{array}$ & $\begin{array}{c}8.5260 * * * \\
(1.931)\end{array}$ & $\begin{array}{c}-7.5731^{* *} \\
(3.049)\end{array}$ & $\begin{array}{c}-0.1208^{* * *} \\
(0.022)\end{array}$ & $\begin{array}{c}-7.7788^{* * *} \\
(2.852)\end{array}$ & $\begin{array}{c}-0.1510^{* * *} \\
(0.029)\end{array}$ \\
\hline Housekeepers and Gardeners & $\begin{array}{c}-1.4036^{*} \\
(0.800)\end{array}$ & $\begin{array}{l}-0.9411 \\
(0.802)\end{array}$ & $\begin{array}{l}-1.8427 \\
(2.753)\end{array}$ & $\begin{array}{l}0.0268 \\
(0.019)\end{array}$ & $\begin{array}{l}-6.7964 \\
(4.357)\end{array}$ & $\begin{array}{l}-0.0229 \\
(0.022)\end{array}$ \\
\hline Construction Workers & $\begin{array}{c}-4.5757^{* * *} \\
(0.978)\end{array}$ & $\begin{array}{c}-5.1251^{* * *} \\
(1.660)\end{array}$ & $\begin{array}{l}-1.4568 \\
(1.845)\end{array}$ & $\begin{array}{l}-0.0037 \\
(0.054)\end{array}$ & $\begin{array}{l}1.0744 \\
(2.080)\end{array}$ & $\begin{array}{l}0.0527 \\
(0.051)\end{array}$ \\
\hline All other (no college) & $\begin{array}{c}-2.6132 * * * \\
(0.596)\end{array}$ & $\begin{array}{c}-1.0228^{* *} \\
(0.465)\end{array}$ & $\begin{array}{l}0.9326 \\
(2.694)\end{array}$ & $\begin{array}{c}1.3147^{* *} \\
(0.642)\end{array}$ & $\begin{array}{l}1.5035 \\
(2.669)\end{array}$ & $\begin{array}{c}1.7341^{* *} \\
(0.675)\end{array}$ \\
\hline All other & $\begin{array}{l}-0.7425 \\
(1.059)\end{array}$ & $\begin{array}{l}0.0790 \\
(0.099)\end{array}$ & $\begin{array}{l}-1.4946 \\
(1.526)\end{array}$ & $\begin{array}{l}-0.0763 \\
(0.095)\end{array}$ & $\begin{array}{l}-1.0322 \\
(1.415)\end{array}$ & $\begin{array}{l}-0.0712 \\
(0.091)\end{array}$ \\
\hline
\end{tabular}

Notes: Each cell represents key coefficient on share less-educated immigrant from a different 2SLS regression at the CZ-year level.

Regressions weighted by CZ working age population. Controls include CZ and year fixed effects.Standard errors clustered at the CZ level.

*** $p<0.01, * * p<0.05, * p<0.1$. 